\title{
Food sources of macrozoobenthos in an Arctic kelp belt: trophic relationships revealed by stable isotope and fatty acid analyses
}

\author{
M. Paar ${ }^{1,5, *}$, B. Lebreton ${ }^{2}$, M. Graeve ${ }^{3}$, M. Greenacre ${ }^{4}$, R. Asmus ${ }^{1}$, H. Asmus ${ }^{1}$ \\ ${ }^{1}$ Wattenmeerstation Sylt, Alfred-Wegener-Institut Helmholtz-Zentrum für Polar- und Meeresforschung, Hafenstraße 43, \\ 25992 List/Sylt, Germany \\ ${ }^{2}$ UMR 7266 Littoral, Environment and Societies, Institut du littoral et de l'environnement, CNRS-University of La Rochelle, \\ 2 rue Olympes de Gouges, 17000 La Rochelle, France \\ ${ }^{3}$ Alfred-Wegener-Institut Helmholtz-Zentrum für Polar- und Meeresforschung, Am Handelshafen 12, 27570 Bremerhaven, \\ Germany \\ ${ }^{4}$ Department of Economics and Business, Universitat Pompeu Fabra and Barcelona Graduate School of Economics, \\ Ramon Trias Fargas, 25-27, 08005 Barcelona, Spain \\ ${ }^{5}$ Present address: Biologische Station Hiddensee, Universität Greifswald, Biologenweg 15, 18565 Kloster, Germany
}

\begin{abstract}
Arctic kelp belts, made of large perennial macroalgae of the order Laminariales, are expanding because of rising temperatures and reduced sea ice cover of coastal waters. In summer 2013, the trophic relationships within a kelp belt food web in Kongsfjorden (Spitsbergen) were determined using fatty acid and stable isotope analyses. Low relative proportions of Phaeophyta fatty acid trophic markers (i.e. 20:4(n-6), 18:3(n-3) and 18:2(n-6)) in consumers (3.3-8.9\%), as well as low 20:4(n-6)/20:5(n-3) ratios $(<0.1-0.6)$, indicated that Phaeophyta were poorly used by macrozoobenthos as a food source, either fresh or as detritus. Relatively high $\delta^{13} \mathrm{C}$ values measured in macrozoobenthos ( -22.5 to $-16.1 \%$ ) ruled out an important role of erect Rhodophyta, which were much more ${ }^{13} \mathrm{C}$ depleted $(-37.1$ to $-35.8 \%)$. Instead, $\delta^{13} \mathrm{C}$ values and relatively high abundances of typical diatom (14:0, 16:1(n-7), 20:5(n-3)) and flagellate (18:4(n-3), 22:6(n-3)) fatty acid trophic markers in consumers pointed out an important use of microalgae, likely of pelagic and benthic origin (i.e. senescent phytoplankton bloom, eroded epiphytes and suspended epilithic material). The use of these food resources may be fostered by their trapping under the kelp canopy.
\end{abstract}

KEY WORDS: Food web · Polar coastal ecosystem · Trophic markers · Macrofauna $\cdot$ Macroalgae · Detritus

\section{INTRODUCTION}

Arctic kelp belts are structurally and functionally diverse coastal habitats and host a rich fauna (Lippert et al. 2001, Włodarska-Kowalczuk et al. 2009) dominated by filter-feeding invertebrates (Paar et al. 2016). This fauna constitutes an important link between primary producers and higher trophic levels such as fishes and seabirds (Fredriksen 2003, Norderhaug et al. 2005). Among primary producers,

${ }^{*}$ Corresponding author: martin.paar@uni-greifswald.de kelps, which are perennial macroalgae of the order Laminariales, can represent very high biomasses and production (Abdullah \& Fredriksen 2004, Bartsch et al. 2016 ) and largely contribute to the functioning of coastal food webs in the Arctic. However, grazers seldom consume more than $10 \%$ of the kelp biomass (Mann 2000), possibly because of its relatively poor quality, i.e. high C:N ratio and high phlorotannin concentrations (Norderhaug et al. 2003). Kelp is known to enter the food chain mostly as detrital

() The authors 2019. Open Access under Creative Commons by Attribution Licence. Use, distribution and reproduction are unrestricted. Authors and original publication must be credited. 
organic matter after bacterial degradation (Norderhaug et al. 2003, Leclerc et al. 2013b). In addition to kelp, consumers can utilize several other primary producers (e.g. phytoplankton, epiphytes) as food resources which are of much higher quality (Cebrian 1999). All these primary producers follow seasonal variations, affecting their biomass and composition and influencing their quality as food resources and their availability to consumers (Wiencke et al. 2009, Hodal et al. 2012). The role of kelp production in Arctic kelp belt food webs, relative to that of other benthic and pelagic primary producers, remains poorly understood on a spatial and temporal scale.

In Kongsfjorden (western coast of Spitsbergen, Svalbard, Norway), the estimated annual primary production of kelp ranges between 400 and $1900 \mathrm{~g} \mathrm{C}$ $\mathrm{m}^{-2} \mathrm{yr}^{-1}$ (Welch et al. 1992, Abdullah \& Fredriksen 2004) - which exceeds considerably the pelagic primary production (i.e. $27-35 \mathrm{~g} \mathrm{C} \mathrm{m}^{-2} \mathrm{yr}^{-1}$, Hodal et al. 2012) - and macroalgal belts cover $44 \%$ of the subtidal area comprised from 0 to $10 \mathrm{~m}$ in this fjord (Kruss et al. 2008, Woelfel et al. 2010). The functioning of the Kongsfjorden's ecosystem has been extensively studied during the past decades, particularly because the frequent influence of warm Atlantic water masses in this fjord (Cottier et al. 2005, 2007) may impact benthic communities. Bartsch et al. (2016) highlighted that biomass of macroalgae increased from 1996-1998 to 2012-2013 and that the peak of biomass shifted to a shallower depth within the intertidal. Changes in biomass also occurred in kelp belts inhabiting macrofaunal communities within this period. While biomass and secondary production increased with depth in 1996 to 1998, the inverse pattern was observed in 2012 to 2013 (Paar et al. 2016). Most of the studies about the benthic food web in Kongsfjorden were done on a broad scale (i.e. the fjord), demonstrating that benthic communities are mainly fueled by pelagic production and settled particulate organic matter (Renaud et al. 2011, Kędra et al. 2012). The trophic interactions of the subtidal kelp belt food webs in Kongsfjorden, however, have been very poorly studied until now, and the feeding ecology of the inhabitant fauna is largely unknown.

More recent studies about trophic relationships in Arctic ecosystems-based on the combination of bulk stable isotope (SI) and conventional fatty acid (FA) analyses - have shown the benefit of using these 2 trophic markers in understanding the functioning of complex benthic food webs (McMahon et al. 2006, Connelly et al. 2014, Legeżyńska et al. 2014). Primary and secondary producers synthesize specific FAs, some of which, especially highly unsaturated
FAs, are incorporated largely unchanged by consumers. These FAs can be used as FA trophic markers to trace the trophic transfers from lower to higher trophic levels and to describe food web functioning (Dalsgaard et al. 2003). Kelp material can generally be distinguished from other primary producers by its high amounts of the 20:4(n-6), 18:4(n-3) and 18:3(n-3) FAs (Graeve et al. 2002), while bacteria are characterized by odd-numbered and branched FAs (Dalsgaard et al. 2003). The use of FAs as trophic markers in benthic habitats might be obscured by low levels of lipid accumulation in benthic taxa (Graeve et al. 1997), the diversity and variability of available food sources, and the ability of consumers to modify FA structures (Kelly \& Scheibling 2012) and the diversity of their feeding modes. Combining SI and FA trophic markers can overcome these limits by means of crossvalidation. Moreover, it gives new insights about the trophic relationships in complex ecosystems, as FAs may allow discriminating food sources with overlapping SI values (Wold et al. 2011).

The present study aims to understand how and to what extent kelp production enters the benthic food web in an Arctic kelp belt (Hansneset, Kongsfjorden, Spitsbergen), either through direct grazing or as detrital matter. Besides kelp material, this study aims to determine which other food resources are utilized by the benthic consumers and if these consumers exhibit different food preferences in relation to their feeding types. Therefore, we analyzed the SI and FA compositions of the major macroalgae and composite food sources of pelagic (i.e. suspended particulate organic matter [SPOM]) and benthic (i.e. epilithic organic matter $[\mathrm{EOM}]$, trapped particulate organic matter [TPOM]) origin in the kelp belt. The links between these potential food sources and macrozoobenthos were investigated by characterizing SI and FA compositions of kelp belt dominant consumers (Paar et al. 2016).

\section{MATERIALS AND METHODS}

\subsection{Study area}

Sampling was conducted in a kelp belt at Hansneset $\left(78^{\circ} 59^{\prime} \mathrm{N}, 11^{\circ} 57^{\prime} \mathrm{E}\right)$ on the west coast of Blomstrandhalvøya, in the central part of the Arctic Kongsfjorden, from June to August 2013 (Fig. 1). This $26 \mathrm{~km}$ long fjord is oriented along a northwestsoutheast axis and receives freshwater inflow from 4 tidal glaciers (Zajączkowski 2008). Long-term average summer temperature (2001-2015) was $2.9^{\circ} \mathrm{C}$ for 


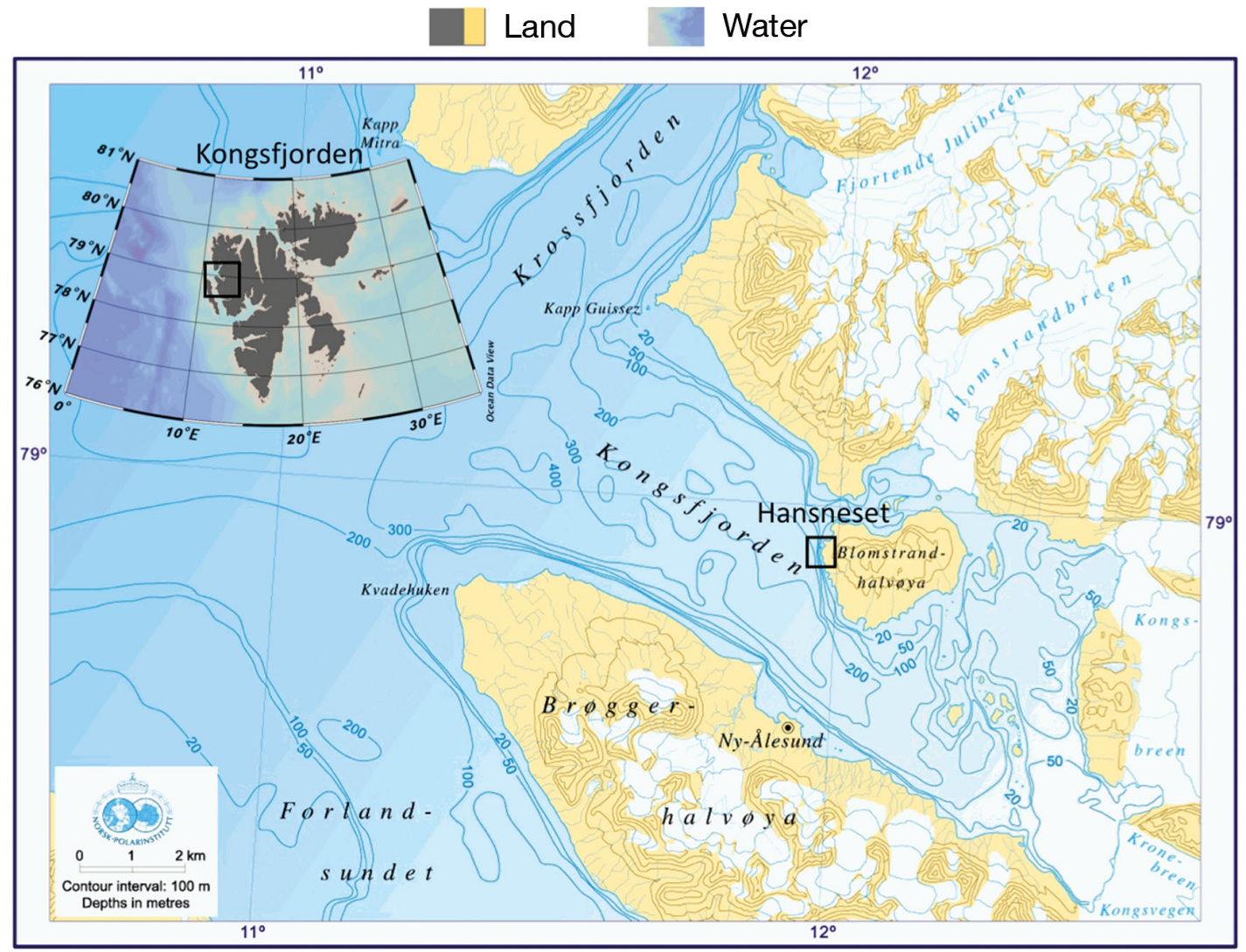

Fig. 1. Subtidal sampling site at Hansneset, west shore of Blomstrandhalvøya, in central Kongsfjorden $\left(78^{\circ} 59.101^{\prime} \mathrm{N}\right.$ $11^{\circ} 57.793^{\prime}$ E) in Spitsbergen (Svalbard archipelago, Norway). Overview maps were created with Ocean Data View (Schlitzer 2018). Map of Kongsfjorden was provided by the Norsk Polarinstitute

Kongsfjorden waters (Promińska et al. 2017). Higher inflow of Atlantic water in the fjord can alter water masses and lead to higher water temperatures above $0^{\circ} \mathrm{C}$ during winter and over $5^{\circ} \mathrm{C}$ during summer (Cottier et al. 2005, 2007). The average tidal range is $1.8 \mathrm{~m}$ (Wangensteen et al. 2007).

At Hansneset, the subtidal bedrock slope is at an angle of about $40^{\circ}$ and is moderately exposed to waves. Terraces and projections seldom interrupt the slope. Down to $15 \mathrm{~m}$ depth, bedrock dominates with depressions filled with sediment and pebbles. Further down, bedrock becomes increasingly covered by sediments. Dense macroalgal vegetation covers the seafloor down to about $30 \mathrm{~m}$ depth (Wiencke et al. 2004, Hop et al. 2012). In coastal waters at Hansneset, sedimentation, light penetration and salinity are highly variable between seasons (Hanelt et al. 2001), which is possibly linked to precipitation, snow and melting of glaciers, bringing freshwater and terrestrial material into the fjord during summer months (Svendson et al. 2002).

The biomasses of macroalgae (Bartsch et al. 2016) and macrozoobenthos (Paar et al. 2016) were investigated during parallel studies in 2012 to 2013 (Fig. 2). The macroalgal biomass was dominated by
Phaeophyta, especially kelp of the order Laminariales, throughout all depths from 2.5 to $10 \mathrm{~m}$, while erect Rhodophyta (Ptilota gunneri, Phycodris rubens, Euthora cristata) were prominent at $15 \mathrm{~m}$ (Bartsch et
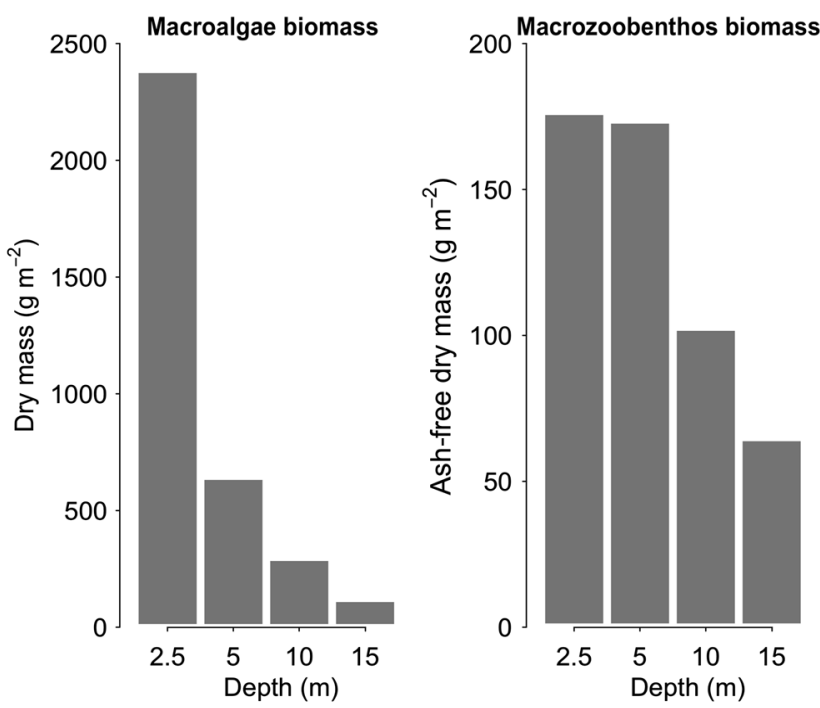

Fig. 2. Distributions of macroalgae (left panel) and macrozoobenthos (right panel) biomass along the depth gradient at Hansneset, Kongsfjorden, based on Bartsch et al. (2016) and Paar et al. (2016) 
al. 2016). Among the macrofauna, sessile suspension feeders dominated the biomass at all depths, representing on average $74 \%$ of the total biomass. At $2.5 \mathrm{~m}$ depth, bryozoans contributed to most of the biomass ( $49 \%$ of the biomass), whereas barnacles were the dominant part of the biomass (42-54\% of the biomass) at deeper depths. The green sea urchin Strongylocentrotus droebachiensis and spider crab Hyas araneus together contributed a maximum of $33 \%$ of the total biomass at depths between 10 and $15 \mathrm{~m}$ (Paar et al. 2016).

\subsection{Environmental data}

Oceanographic parameters (i.e. temperature, turbidity) were continuously recorded in summer 2013 by the AWIPEV-COSYNA underwater long-term fjord observatory at $11 \mathrm{~m}$ water depth at the old pier in Nansen Bay $\left(78^{\circ} 59\right.$ N, 11 55 E). For chl a analysis, surface water samples were collected at Hansneset on a weekly basis between June and September 2013 (Table 1). From 90 to $270 \mathrm{ml}$ was filtered on precombusted ( $4 \mathrm{~h}$ at $450^{\circ} \mathrm{C}$ ) Whatman $\mathrm{GF} / \mathrm{F}$ glass fiber filters in triplicate, immediately after sample collection. Filters were frozen at $-20^{\circ} \mathrm{C}$ and stored in darkness. $\mathrm{Chl} \mathrm{a}$ on the filters was extracted in $90 \%$ acetone for 4 to $8 \mathrm{~h}$ in the dark at approximately $6^{\circ} \mathrm{C}$ and meas- ured at wavelengths of 750,663, 645 and $630 \mathrm{~nm}$ using a UVIKON XL spectrophotometer (Goebel Instrumentelle Analytik).

\subsection{Sample collection and preparation for SI and FA analyses}

Potential food sources and consumers (Table 2) were sampled by SCUBA diving at 2.5 to $15 \mathrm{~m}$ water depth within the main extension of the kelp belt (Bartsch et al. 2016) from June to August 2013. Food sources and consumers were collected at the beginning and from the middle until the end of the field campaign, respectively, considering a time lag between consumption and integration of the trophic marker signals within tissues of the consumers (see Table 1 for more details about sample collection).

Phaeophyta were too large to be entirely ground. They were blotted dry, and then 3 discs $(13 \mathrm{~mm}$ diameter) were punched out of the blades at approximately 0, 20 and $40 \mathrm{~cm}$ from the blade meristem. In addition, 3 pieces of stipe (1 $\mathrm{cm}$ long) were cut directly above the holdfast, in the middle of the stipe and beneath the blade. Blade discs and pieces of stipe were then grouped, to have 2 representative samples for each algae, 1 for the blade and 1 for the stipe. Rhodophyta were blotted dry, and whole

Table 1. Information about samples for environmental parameters and trophic marker analyses in the kelp belt at Hansneset. SI: stable isotopes; FA: fatty acids; SPOM: suspended particulate organic matter; EOM: epilithic organic matter; TPOM: trapped particulate organic matter; SR: sedimentation rate; NA: not analyzed; -: not applicable

\begin{tabular}{|c|c|c|c|c|c|c|}
\hline Sample type & Location & Period in 2013 & Frequency & $\begin{array}{l}\text { Sample size } \\
\text { for SI }\end{array}$ & $\begin{array}{l}\text { No. of ind. } \\
\text { for FA }\end{array}$ & $\begin{array}{c}\text { Measurement/ } \\
\text { analysis }\end{array}$ \\
\hline Seawater & Nansen Bay & June-September & $5 \mathrm{~min}$ & NA & NA & Temperature, turbidity \\
\hline SPOM & Hansneset & June-September & $7 \mathrm{~d}$ & 3 & - & $\mathrm{Chl} a, \mathrm{SI}, \mathrm{FA}$ \\
\hline Macroalgae & Hansneset & June-July & Once & 3 per species & 3 per species & SI, FA \\
\hline Epiphytes & Hansneset & June-July & Once & 3 & -1 & SI, FA \\
\hline Detritus & Hansneset & June-July & Once & 3 & NA & SI \\
\hline EOM & Hansneset & June-July & Once & 3 & - & SI, FA \\
\hline TPOM & Hansneset & July-August & $15 \mathrm{~d}$ & 6 & - & SI, FA, SR \\
\hline Bryozoa & Hansneset & July-September & Once & 3 & - & SI, FA \\
\hline Balanus sp. & Hansneset & July-September & Once & 3 & 19 & SI, FA \\
\hline Synoicum turgens & Hansneset & July-September & Once & 3 & 20 & SI, FA \\
\hline Hiatella arctica & Hansneset & July-September & Once & 3 & 10 & SI, FA \\
\hline Musculus sp. & Hansneset & July-September & Once & 3 & 17 & SI, FA \\
\hline Caprella septentrionalis & Hansneset & July-September & Once & 3 & 31 & SI, FA \\
\hline Hyas araneus & Hansneset & July-September & Once & 3 & 6 & SI, FA \\
\hline Margarites groenlandicus & Hansneset & July-September & Once & 3 & 20 & SI, FA \\
\hline Tonicella rubra & Hansneset & July-September & Once & 3 & 11 & SI, FA \\
\hline Ophiopholis aculeata & Hansneset & July-September & Once & 3 & 7 & SI, FA \\
\hline Strongylocentrotus droebachiensis & Hansneset & July-September & Once & 3 & 8 & SI, FA \\
\hline Other macrozoobenthos & Hansneset & July-September & Once & 3 per species & NA & SI \\
\hline
\end{tabular}


Table 2. Macrozoobenthic species sampled for stable isotope analyses. Feeding type was taken from literature

\begin{tabular}{|c|c|c|c|c|}
\hline Phylum & Class & Taxon sampled & Feeding type & Reference \\
\hline Chlorophyta & & Acrosiphonia spp. $^{\mathrm{a}}$ & Primary producer & \\
\hline \multirow[t]{3}{*}{ Rhodophyta } & & Phycodrys rubens ${ }^{\mathrm{a}}$ & Primary producer & \\
\hline & & Ptilota gunneri & Primary producer & \\
\hline & & Corallinales $^{\mathrm{a}}$ & Primary producer & \\
\hline \multirow[t]{7}{*}{ Phaeophyta } & & Desmarestia aculeata $^{\mathrm{a}}$ & Primary producer & \\
\hline & & Alaria esculenta ${ }^{\mathrm{a}}$ & Primary producer & \\
\hline & & Laminaria digitata $^{\mathrm{a}}$ & Primary producer & \\
\hline & & Saccharina latissima ${ }^{\mathrm{a}}$ & Primary producer & \\
\hline & & Saccorhiza dermatodea ${ }^{a}$ & Primary producer & \\
\hline & & Pseudolithoderma sp. ${ }^{\mathrm{a}}$ & Primary producer & \\
\hline & & Chordariacea $^{\mathrm{a}}$ & Primary producer & \\
\hline Annelida & Polychaeta & Hediste diversicolor & Omnivore & Nielsen et al. (1995) \\
\hline Bryozoa $^{\mathrm{a}}$ & & & Filter feeder & Barnes \& Clarke (1994) \\
\hline \multirow[t]{5}{*}{ Crustacea } & Decapoda & Hyas araneus ${ }^{\mathrm{a}}$ & Omnivore & Berge et al. (2009) \\
\hline & & Pagurus pubescens & Omnivore & Berge et al. (2009) \\
\hline & Amphipoda & Gammarellus homari & Grazer & Wessels et al. (2011) \\
\hline & & Caprella septentrionalis ${ }^{\mathrm{a}}$ & Filter feeder & $\begin{array}{l}\text { Guerra-García \& } \\
\text { Tierno de Figueroa (2009) }\end{array}$ \\
\hline & Cirripedia & Balanus sp. ${ }^{\mathrm{a}}$ & Filter feeder & Eckman \& Duggins (1993) \\
\hline \multirow[t]{2}{*}{ Chordata } & Ascidiacea & Synoicum turgens ${ }^{\mathrm{a}}$ & Filter feeder & Petersen (2007) \\
\hline & & Halocynthia pyriformes & Filter feeder & Petersen (2007) \\
\hline \multirow[t]{2}{*}{$\begin{array}{l}\text { Echino- } \\
\text { dermata }\end{array}$} & Echinoidea & $\begin{array}{l}\text { Strongylocentrotus } \\
\text { droebachiensis }^{\mathrm{a}}\end{array}$ & Grazer & Brown et al. (2012) \\
\hline & Ophiuroidae & Ophiopholis aculeata ${ }^{\mathrm{a}}$ & Omnivore & Graeve et al. (1997) \\
\hline \multirow[t]{6}{*}{ Mollusca } & Bivalvia & Hiatella arctica ${ }^{\mathrm{a}}$ & Filter feeder & Petersen et al. (2003) \\
\hline & & Musculus sp. ${ }^{\mathrm{a}}$ & Filter feeder & Beninger et al. (1991) \\
\hline & Gastropoda & Margarites groenlandicus ${ }^{\mathrm{a}}$ & Grazer & \\
\hline & & Boreotrophon truncatus & Grazer & \\
\hline & & Buccinum sp. & Omnivore & Himmelman \& Hamel (1993) \\
\hline & Polyplacophora & Tonicella rubra ${ }^{\mathrm{a}}$ & Grazer & Latyshev et al. (2004) \\
\hline Porifera & Calcarea & Sycon sp. & Filter feeder & \\
\hline
\end{tabular}

organisms were taken for the analysis. Encrusting Corallinaceae (ENCO) and encrusting Rhodophyta (ENRH) were scraped from rocks using a razor blade. Detritus was collected within the sampled flora and fauna in $500 \mu \mathrm{m}$ mesh bags in the field, then washed from the samples and carefully collected on a $250 \mu \mathrm{m}$ mesh sieve in the laboratory. All samples were freeze dried and then ground to a fine, homogeneous powder using a ball mill (MM 400, Retsch). Samples were stored at $-20^{\circ} \mathrm{C}$ for SI analyses and at $-80^{\circ} \mathrm{C}$ under a nitrogen atmosphere for FA analyses.

Epiphytes of Laminariales were collected by brushing the blades using a soft plastic brush and thereafter carefully rinsed with filtered seawater. The mixture of epiphytes was filtered on precombusted Whatman GF/F glass fiber filters under moderate vacuum (minimum -30 kPa). Surface water was sampled directly above the kelp belt to extract SPOM. For SI, SPOM was collected on a weekly basis (3 replicates per sampling) to study intra-seasonal variations. A volume of seawater from 80 to $180 \mathrm{ml}$ for SI and from 30 to 451 for FA analyses was prefiltered on a $250 \mu \mathrm{m}$ mesh sieve to eliminate zooplankton and large detrital particles. Pre-filtered water was drawn through precombusted Whatman GF/F glass fiber filters under moderate vacuum. EOM was sampled from drop stones collected at $8 \mathrm{~m}$ depth. Stone surfaces were brushed with a soft plastic brush and thereafter carefully rinsed with filtered seawater. The extracted solution was filtered on precombusted Whatman GF/F glass fiber filters under moderate vacuum. All filters (i.e. epiphytes, SPOM, EOM) were freeze dried and then stored in the same manner as other food sources.

Six sediment traps (Cylindrical Sedimentation Vessel, $140 \mathrm{~mm}$ diameter and $560 \mathrm{~mm}$ length, HydroBios) were equipped with sample bottles at the bottom, into which sedimented material could accumulate. TPOM samples were collected every $2 \mathrm{wk}$ from the beginning of July to the end of August 2013. At 
the laboratory, samples were decanted in 1 l glass cylinders, and the supernatant was discarded after complete sedimentation. The residues were carefully collected, freeze dried and stored in the same manner as other food sources.

Dominant macrozoobenthic species (Table 2), representing together more than $90 \%$ of the total macrozoobenthic biomass, were sampled following methods detailed in Paar et al. (2016). All animals were kept alive for $36 \mathrm{~h}$ in filtered seawater to allow for gut content evacuation before storage at -20 or $-80^{\circ} \mathrm{C}$ under nitrogen atmosphere for SI and FA analyses, respectively. Soft tissues of barnacles and mollusks were removed from their shells. All samples were freeze dried and ground using a ball mill. For SI analyses, 3 entire individuals (1 small, 1 medium, 1 large) were analyzed individually to represent the size range of the whole population, except for the skeleton shrimp Caprella septentrionalis, whose smallest individuals were pooled into groups of 5 individuals to obtain enough material. For FA analyses, 3 to 31 entire individuals per species, depending on their size, were pooled, and 1 analysis was carried out on each pool (see Table 1 for more details about sample collection). This procedure provided enough material for FA analyses and lowered the intraspecific variability.

\subsection{SI sample preparation and analyses}

Carbonates were removed from filters (i.e. SPOM, $\mathrm{EOM}$ ) for $\delta^{13} \mathrm{C}$ measurements by contact with $\mathrm{HCl}$ fumes in a vacuum-enclosed system for $4 \mathrm{~h}$. Lipid removal prior to SI analysis was not necessary because of the overall low lipid content in sources and consumers. TPOM was acidified by adding $\mathrm{HCl}$ at $1 \mathrm{~mol} \mathrm{l}^{-1}$ drop by drop until cessation of bubbling; then, samples were dried in a dry block heater, freeze dried and ground again. No treatment was applied to samples for $\delta^{15} \mathrm{~N}$ measurements, as acidification may affect isotope composition of nitrogen (Jacob et al. 2005). Samples were analyzed using an elemental analyzer (FlashEA 1112, Thermo Scientific) coupled with an isotope ratio mass spectrometer (DELTA V Advantage with a ConFlo IV interface, Thermo Scientific) at the LIENSs SI facility of the University of La Rochelle, France. Isotope values are expressed using the $\delta$ notation as deviations from international standards (Vienna Pee Dee Belemnite for $\delta^{13} \mathrm{C}$ and $\mathrm{N}_{2}$ in air for $\delta^{15} \mathrm{~N}$ ) following the formula $\delta^{13} \mathrm{C}$ or $\delta^{15} \mathrm{~N}=\left[\left(R_{\text {sample }} / R_{\text {standard }}\right)-1\right] \times 10^{3}$, where $R$ is ${ }^{13} \mathrm{C} /{ }^{12} \mathrm{C}$ or ${ }^{15} \mathrm{~N} /{ }^{14} \mathrm{~N}$, respectively. The $\delta$ SI values were calculated from mass spectrometer readings using Isodat 3.0 software (Thermo Fisher Scientific). Calibration was done using reference materials (USGS24, IAEA-CH-6, IAEA-600 for carbon; IAEA-N-2, IAEA-NO-3, IAEA-600 for nitrogen). Analytical precision based on the analyses of acetanilide (Thermo Fisher Scientific) used as the laboratory internal standard was $<0.15 \%$ for carbon and nitrogen.

\subsection{Lipid extraction and FA analyses}

Lipids were extracted from freeze-dried powders with an accelerated solvent extractor (ASE 200, Dionex) using a slightly modified procedure from Folch et al. (1957). Samples were extracted 3 successive times with mixtures of chloroform:methanol (1:2, $2: 1$ and $4: 1, \mathrm{v} / \mathrm{v})$. A volume of $1 \%$ sodium chloride solution was added and the mixture separated into 2 phases. The lower layer containing lipids was collected and water removed by addition of dry sodium sulfate. Total lipid content was determined on 5 replicates by flame ionization detection (FID) using an MK-6s Iatroscan (Mitsubishi Chemical). The FID response was calibrated using cod liver oil as a standard. The extracted lipids were transmethylated by acid catalysis at $80^{\circ} \mathrm{C}$ for $2 \mathrm{~h}$ in $\mathrm{H}_{2} \mathrm{SO}_{4}$-methanol $(4 \%, \mathrm{w} / \mathrm{v})$ reagent (Christie 1984) with addition of toluene $(10 \%, v / v)$ to yield FA methyl esters (FAMEs). Water was added and FAMEs were extracted twice with hexane. FAMEs were then purified in 2 steps using a high-performance liquid chromatograph following the same procedures as in Lebreton et al. (2011). FAMEs were analyzed using a gas chromatograph (GC-6890N, Agilent Technologies) fitted with a J\&W DB-23 capillary column (60 m, $0.25 \mathrm{~mm}$ internal diameter, $0.25 \mu \mathrm{m}$ film). Injector and FID detector temperatures were set at 240 and $260^{\circ} \mathrm{C}$, respectively. Hydrogen was used as a carrier gas in constant flow mode at an average linear velocity of $30 \mathrm{~cm}$ $\mathrm{s}^{-1}$. A linear temperature gradient from 100 to $240^{\circ} \mathrm{C}$ at $1^{\circ} \mathrm{C} \mathrm{min}^{-1}$ was used. FAME identification was performed by comparing relative retention times with those of known standard mixtures: C8-C24 mix, 37-FAME mix, 26-BAME mix, and PUFA-1 and PUFA-3 (Supelco, Sigma-Aldrich). Equivalent chain lengths (Christie 1988) were used as an aid in peak localization and identification. Each FAME area was corrected from the corresponding FID response factor (Bannon et al. 1986) and from the difference in mass between the FAME and its corresponding free FA. 


\subsection{Data and statistical analyses}

Isotope compositions of consumers and of food sources were compared using a trophic fractionation factor (TFF) of $0.8 \pm 0.7 \%$ for $\delta^{13} \mathrm{C}$ and $2.7 \pm 0.4 \%$ for $\delta^{15} \mathrm{~N}$ values, which were calculated after the equation for invertebrates given by Caut et al. (2009). The equation from Post (2002) was employed to calculate the trophic level (TL) of each consumer species:

$$
\mathrm{TL}=\frac{\delta^{15} \mathrm{~N}_{\text {consumer }}-\delta^{15} \mathrm{~N}_{\text {baseline }}}{\operatorname{Tff} \delta^{15} \mathrm{~N}}+\mathrm{TL}_{\text {baseline }}
$$

The average $\delta^{15} \mathrm{~N}$ value of the filter feeders was used as a food web baseline $\left(\delta^{15} \mathrm{~N}_{\text {baseline}}\right)$ to avoid issues related to temporal and spatial variability in the primary producers. As a result, the $\mathrm{TL}_{\text {baseline }}$ was considered as 2. Ellipses representing 95\% confidence regions for potential food sources and consumers were computed based on bootstrap resampling using the function CIplot_biv described in Greenacre (2016) using the ellipse R package (Murdoch \& Chow 2018) in R version 3.1.2 (R Core Team 2018). Non-parametric procedures were used to achieve more robust statistics because of small sample sizes (sample size almost always <10) and nonindependence of data within series. Isotope compositions of food sources and consumers were compared using Kruskal-Wallis tests. These tests were followed by multiple comparisons of means using the pgirmess package in R (Giraudoux 2015).

FA data are expressed as the percentage of each FA relative to the sum of all identified FAs. FAs with values lower than $1 \%$ of the total FA composition were removed prior to data analysis in all samples. The principal origin of FA markers was determined using the literature (Table 3), and for trophic relation analysis, FAs were associated with groups of potential food sources (bacteria, flagellates, diatoms, Phaeophyta, macroalgae, vascular plants or animals) or considered as ubiquitous markers. Hierarchical clustering analyses (using the chi-square distance and Ward clustering) were used to compare groups of species formed in the source and consumer FA data sets, using the
R function hierclust by Murtagh (2005). Using a permutation test for clusteredness by Greenacre (2011b), a cut-off level on the dendrogram of the cluster analysis was obtained, identifying clusters that can be considered to be true clusters. Whereas the compositional data would preferably be transformed to logratios (see, for example, Aitchison et al. 2000), these data have many zero values, which preclude taking logarithms. Correspondence analysis, which uses the chi-square distance, was chosen here because it has been shown to have favorable properties for defining distances on compositional data in the presence of zero values (Greenacre 2011a, Kraft et al. 2015).

To enhance the discrimination between primary producers (Phaeophyta, Rhodophyta, Chlorophyta, ENCO, ENRH, epiphytes), composite food sources (SPOM, TPOM, EOM, detritus) and consumers, $\delta^{13} \mathrm{C}$ values were plotted against their ratios of 20:4(n-6)/ 20:5(n-3).

Table 3. Fatty acids used as trophic markers in the kelp belt food web

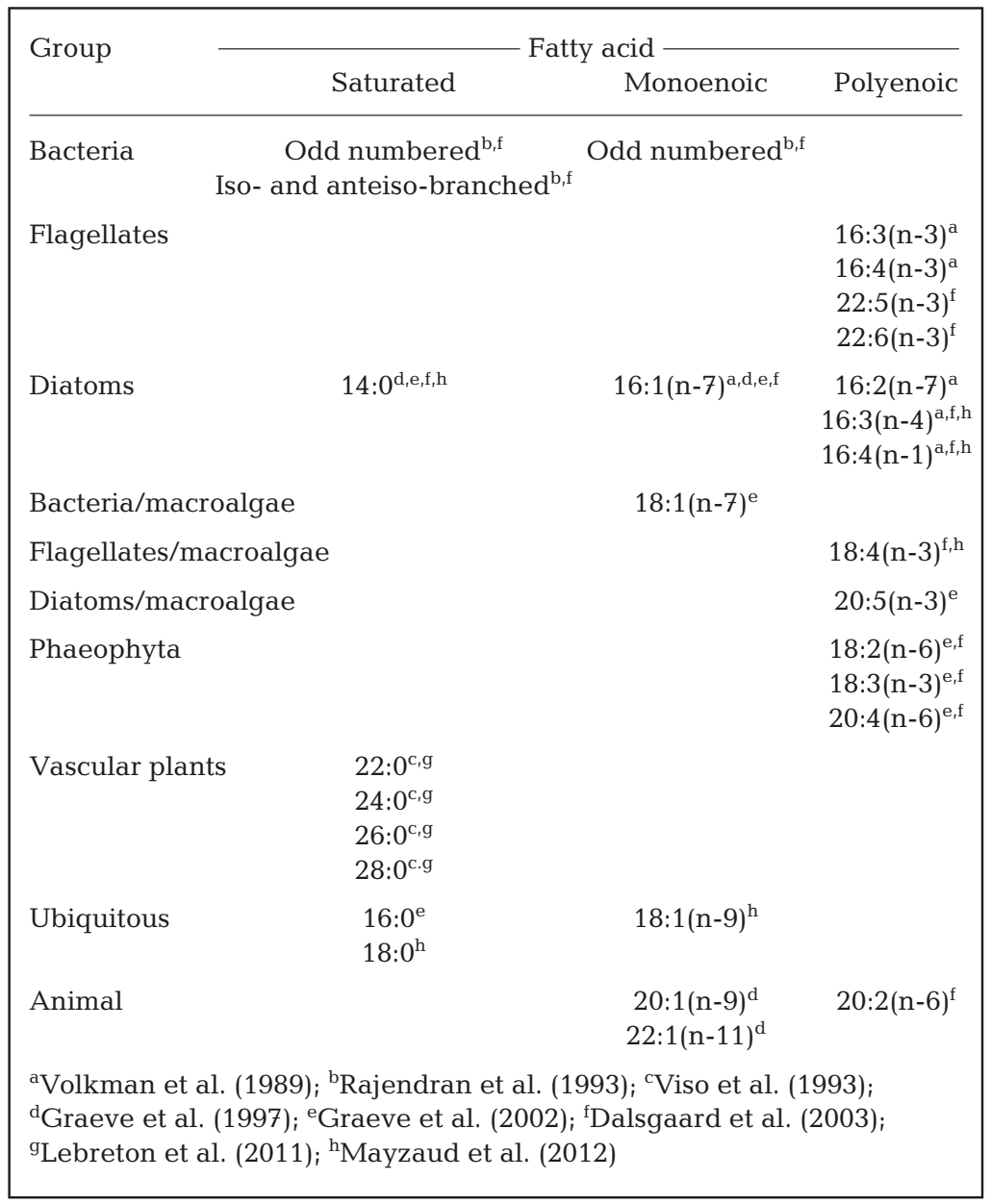




\section{RESULTS}

\subsection{Abiotic parameters}

The seawater surface temperature of Kongsfjorden slowly increased during the survey (6 June-27 August 2013), from 2.2 to $6.4^{\circ} \mathrm{C}$ (Fig. 3). At Hansneset, chl a concentrations ranged from 0.01 to $2.71 \mathrm{mg}$ $\mathrm{m}^{-3}$ between June and August and peaked on 16 August. Sedimentation rates increased considerably from 4 to $20 \mathrm{~g} \mathrm{~m}^{-2} \mathrm{~d}^{-1}$ between July and August in 2013, with a standard deviation ranging from 0.06 to $1.3 \mathrm{~g} \mathrm{~m}^{-2} \mathrm{~d}^{-1}$. Suspended particulate matter concentrations ranged from 4.8 to $6.3 \mathrm{mg} \mathrm{l}^{-1}$ above the macroalgal belt at Hansneset.

\subsection{SI composition of macroalgae}

Mean $\delta^{13} \mathrm{C}$ values of macroalgae ranged from -36.3 to $-17.0 \%$ (Fig. 4, Table S1 in the Supplement at www.int-res.com/articles/suppl/m615p031_supp.pdf). The erect Rhodophyta Phycodrys rubens and Ptilota gunneri (-37.1 to $-35.8 \%$ ) were significantly more ${ }^{13} \mathrm{C}$ depleted than all other food sources $(p=0.001)$. The Phaeophyta Desmarestia aculeata had considerably lower $\delta^{13} \mathrm{C}$ values $(-29.9$ to $-24.8 \%$ ) than the kelp species (i.e. Alaria esculenta, Laminaria digitata, Saccharina latissima and Saccorhiza dermatodea) (-21.0 to $-17.4 \%$, $\mathrm{p}=0.009$ ). The Chlorophyceae Acrosiphonia sp. $\delta^{13} \mathrm{C}$ values ranged between those of $D$. aculeata and kelps. No differences in $\delta^{13} \mathrm{C}$ values $(\mathrm{p}=0.049)$ were found between the kelp species $A$. esculenta, L. digitata, S. latissima and $S$. dermatodea. Epiphytes had $\delta^{13} \mathrm{C}$ values $(-18.7$ to $-17.9 \%$ ) close to kelps.

Mean $\delta^{15} \mathrm{~N}$ values of macroalgae ranged from 3.6 to $5.3 \%$ o (Fig. 4, Table S1). The kelp species L. digitata, S. latissima and $S$. dermatodea were significantly more enriched in ${ }^{15} \mathrm{~N}$ than all other macroalgae, including A. esculenta $(p<$ 0.006). All Rhodophyta had very similar $\delta^{15} \mathrm{~N}$ values (3.6 to $4.3 \%$ ). Epiphytes were slightly more depleted in ${ }^{15} \mathrm{~N}$ (3.3-3.6\%).

\subsection{SI composition of composite food sources}

Detritus from $15 \mathrm{~m}$ (-31.5 to $-29.5 \%)$ was more ${ }^{13} \mathrm{C}$ depleted than detritus from $10 \mathrm{~m}$ ( -25.7 to $-22.4 \%$, Fig. 4). EOM had intermediate $\delta^{13} \mathrm{C}$ values, falling between those of detritus from 15 and $10 \mathrm{~m}$. SPOM $\delta^{13} \mathrm{C}$ values were highly variable, ranging from -31.8 to $-20.5 \%$. In June and the end of August, SPOM was more enriched in ${ }^{13} \mathrm{C}$ ( -24.2 to $-22.9 \%$ and -26.2 to $-18.9 \%$, respectively) than in July and the beginning of August (-31.8 to $-25.7 \%$ ). $\delta^{13} \mathrm{C}$ values of TPOM (-22.5 to $-19.5 \%$, Fig. 4) were the highest among composite food sources and showed a lower variability than those of SPOM.

EOM had very low $\delta^{15} \mathrm{~N}$ values, between 0.7 and $2.0 \%$, being the most ${ }^{15} \mathrm{~N}$ depleted among all potential food sources (Fig. 4). Detritus from $10 \mathrm{~m}$ (4.4-5.7\%o) was more enriched in ${ }^{15} \mathrm{~N}$ compared to detritus from $15 \mathrm{~m}$ water depth (2.6-3.5\%o). SPOM $\delta^{15} \mathrm{~N}$ values decreased from June (5.3-7.1\%) to midAugust (1.5-4.9\%o), then got back in the range of values observed in June at the end of August (i.e. between 2.6 and $5.9 \%$ ). TPOM $\delta^{15} \mathrm{~N}$ values ranged from 1.7 to $4.8 \%$, with the lowest values measured in mid-July.

\subsection{SI composition of consumers}

The different trophic groups (i.e. filter feeders, grazers and omnivores) showed similar average $\delta^{13} \mathrm{C}$ values $(p=0.9)$. Filter feeders had the largest range of carbon isotope compositions, with mean $\delta^{13} \mathrm{C}$ values ranging from -22.5 (Bryozoa) to $-17.1 \%$ o (Sycon sp.) (Fig. 5, Table S1). The range of $\delta^{13} \mathrm{C}$ values was slightly lower for grazers (i.e. from -22.1 to $-18.2 \%$ ). The omnivores exhibited a similar range of $\delta^{13} \mathrm{C}$ val-

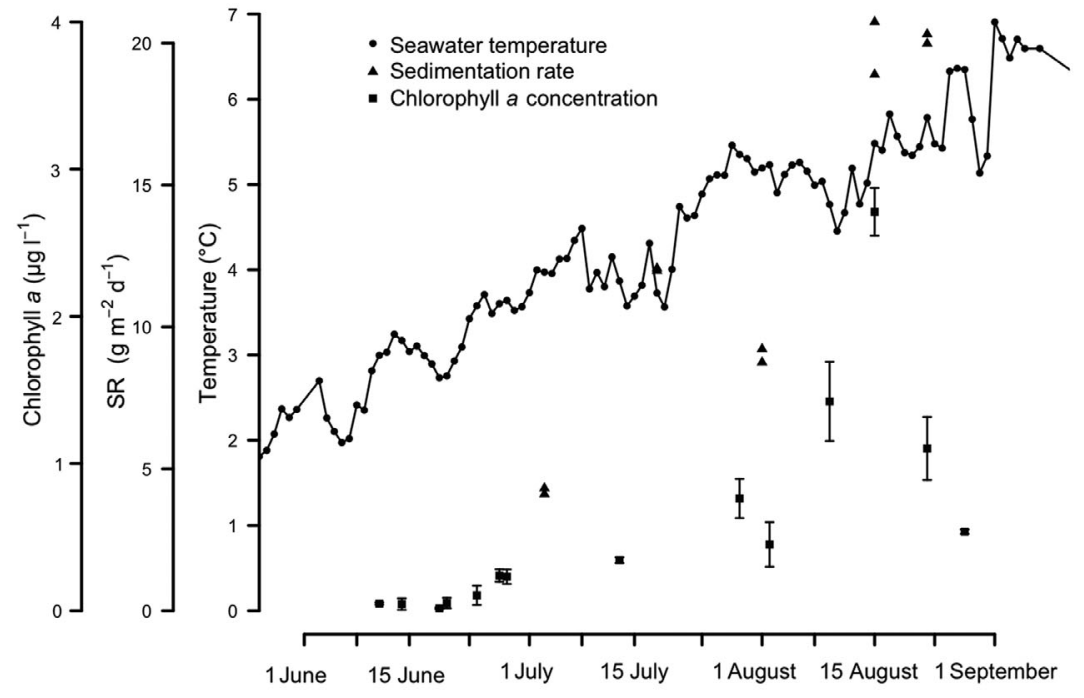

Fig. 3. Daily seawater temperature in Kongsfjorden (data taken from the AWIPEV-COSYNA underwater observatory), and sedimentation rate (SR) and mean chl a concentration at Hansneset. Error bars indicate standard deviations 


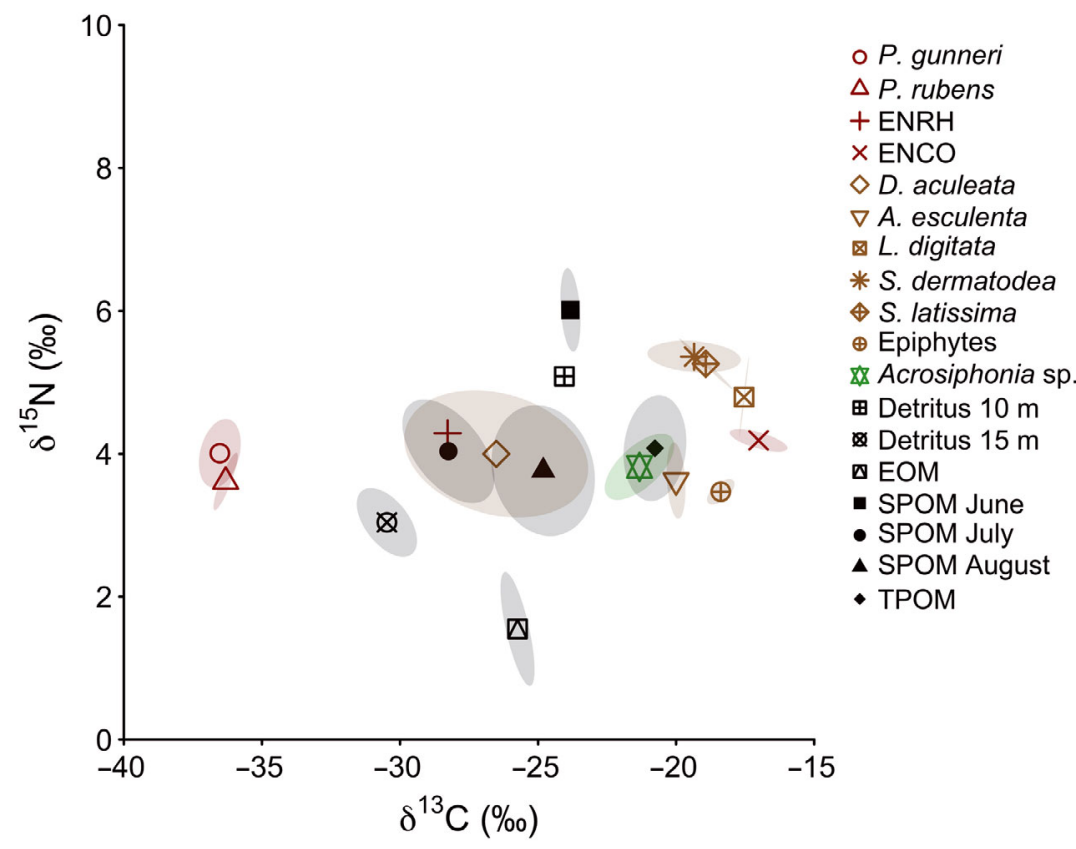

Fig. 4. $\delta^{13} \mathrm{C}$ and $\delta^{15} \mathrm{~N}$ values (mean and $95 \%$ confidence ellipse) of food sources in the macroalgal belt at Hansneset. Species include Alaria esculenta, Desmarestia aculeata, Laminaria digitata, Ptilota gunneri, Phycodrys rubens, Saccorhiza dermatodea, Saccharina latissima. ENRH: encrusting Rhodophyta, ENCO: encrusting Corallinaceae; EOM: epilithic organic matter; SPOM: suspended particulate organic matter; TPOM: trapped particulate organic matter

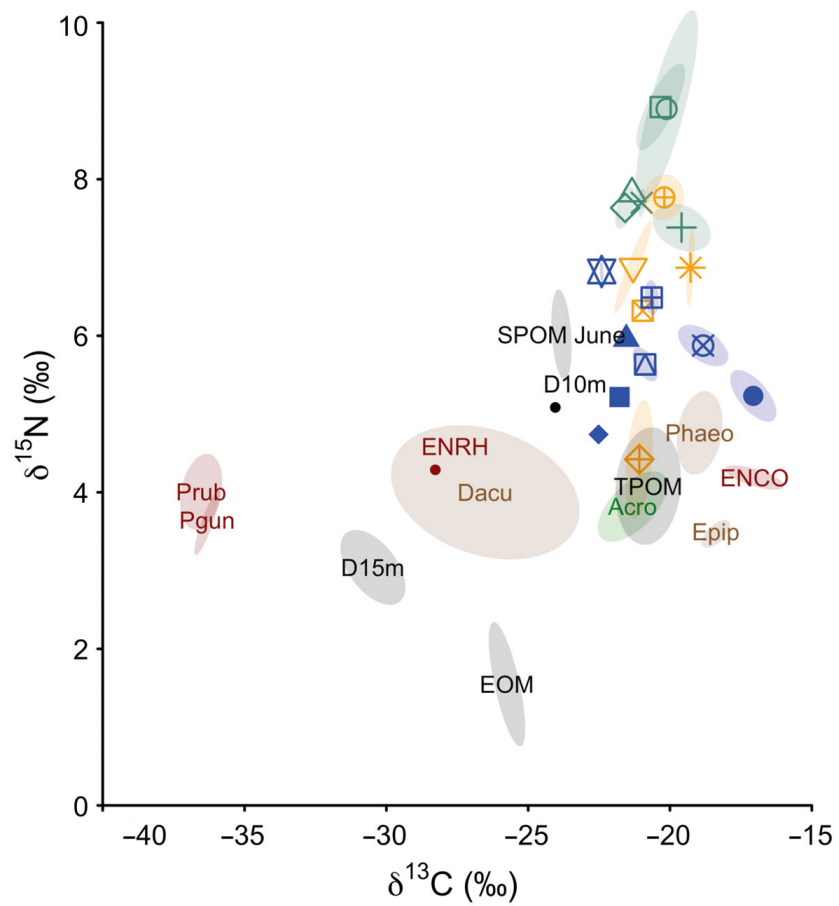

ues as found in the grazers, from the relatively ${ }^{13} \mathrm{C}$-depleted brittle star Ophiopholis aculeata $(-21.9$ to $-21.3 \%$ ) to the more ${ }^{13} \mathrm{C}$-enriched hermit crab Pagurus pubescens $(-20.6$ to $18.8 \%$ o).

The $\delta^{15} \mathrm{~N}$ values of consumers ranged between 3.7 (Strongylocentrotus droebachiensis) and 10.2\% (Hyas araneus) (Fig. 5, Table S1). The sea urchin $S$. droebachiensis was strongly more ${ }^{15} \mathrm{~N}$-depleted than all other consumers $(p<0.0001)$. Other grazers had mean $\delta^{15} \mathrm{~N}$ values ranging from 6.3 (Gammarellus homari) to $7.8 \%$ (Tonicella rubra). Within the filter feeders, bryozoans $(4.7 \%$ ) had the lowest $\delta^{15} \mathrm{~N}$ value while Halocynthia pyriformis was the most ${ }^{15} \mathrm{~N}$ enriched (i.e. $6.8 \%$ ). Omnivores had the highest $\delta^{15} \mathrm{~N}$ values among the consumer trophic guilds, ranging from 7.1 in $P$. pubescens to $10.2 \%$ in $H$. araneus. Filter feeders, grazers and omnivores had calculated TLs ranging from 1.6 to $2.4,1.5$ to 2.7 and 2.6 to 3.2 , respectively (Table S1).

\subsection{FA composition of food sources}

In total, 41 FAs were identified in the analyzed taxa (Fig. 6, Table S2 in

Fig. 5. $\delta^{13} \mathrm{C}$ and $\delta^{15} \mathrm{~N}$ values (mean and $95 \%$ confidence ellipse) of consumers and of some food sources in the macroalgal belt at Hansneset. For readability, only isotope composition of suspended particulate organic matter (SPOM) in June is displayed and isotope compositions of Alaria esculenta, Laminaria digitata, Saccorhiza dermatodea and Saccharina latissima have been grouped under the name Phaeophyta. Food sources: Acro: Acrosiphonia sp.; D10m: detritus 10 m; D15m: detritus 15 m; Dacu: Desmarestia aculeata; Epip: epiphytes; Phaeo: Phaeophyta; Pgun: Ptilota gunneri; Prub: Phycodrys rubens. Other abbreviations as in Fig. 4 
the Supplement). Percentages of saturated longchain FAs typical for vascular plants, such as 24:0, 26:0 and 28:0, were very low in all food sources $(<1 \%)$. Two main groups of sources could be defined based on the cluster analysis: one composed of the Phaeophyta (stipes and blades) and one consisting of $P$. gunneri, ENRH, epiphytes and the composite food sources (Fig. 6). Phaeophyta had a markedly different FA composition from all other sources, as they were generally characterized by high quantities of 18:2(n-6), 20:4(n-6) and 20:5(n-3). Among Phaeophyta, blades and stipes had a relatively different FA composition. The blades were mainly composed of 18:3(n-3), 18:4(n-3) and 20:5(n-3), whereas the stipes had much higher proportions of 16:1(n-7) and 20:4(n6) compared to the blades. Blades of L. digitata, A. esculenta and S. latissima had comparable FA compositions, as did their stipes. The bacterial FA markers (i.e. odd numbered, iso- and anteiso-branched) occurred in low quantities in Phaeophyta $(<2.5 \%)$.

The food sources grouped in the second cluster were more heterogeneous in their FA composition (Fig. 6). P. gunneri (erect Rhodophyta) was characterized by high levels of 20:5(n-3) $(42.6 \%)$ and inter-
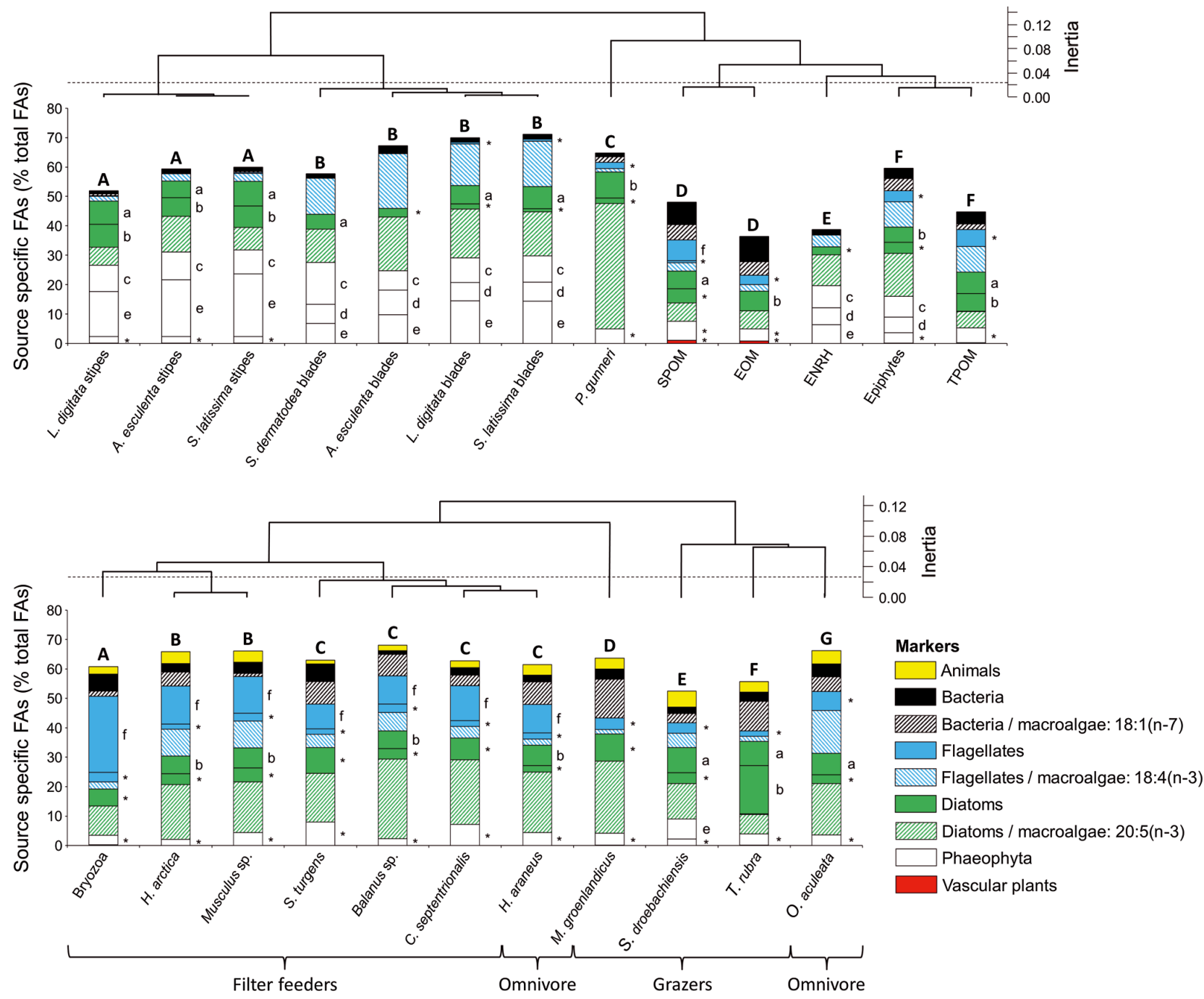

Fig. 6. Relative percentages of fatty acids (FAs) in macroalgae and composite food sources (top panel) and in macrozoobenthos consumers (bottom panel) collected from June to August 2013 at Hansneset. Presented FAs were selected based on their ecological role as trophic markers (Tables S2 \& S3 in the Supplement). Hierarchical clusters (chi-square distance, Ward clustering) are presented. Food sources and consumers with similar FA composition (i.e. same cluster) are identified with upper case letters, with dashed lines representing the cut-off level for significant clusters. FAs are grouped according to their role as trophic markers (see Table 2). FAs with proportions $\geq 5 \%$ are labeled with lower case letters (a: 14:0; b: 16:1(n-7); c: 18:2(n-6); d: 18:3(n-3); e: 20:4(n-6); f: 22:6(n-3)), and asterisks represent the sum of other FAs for each trophic marker group. Species include Alaria esculenta, Caprella septentrionalis, Hiatella arctica, Hyas araneus, Laminaria digitata, Margarites groenlandicus, Ophiopholis aculeata, Ptilota gunneri, Strongylocentrotus droebachiensis, Saccharina latissima, Saccorhiza dermatodea, Synoicum turgens, Tonicella rubra. Other abbreviations as in Fig. 4 
mediate levels of 16:1(n-7) and 18:1(n-9). In contrast, ENRH FA composition was dominated by $18: 1(\mathrm{n}-9)$ $(32.1 \%)$, with a much lower contribution of 20:5(n-3) than in the erect Rhodophyta. Epiphytes and TPOM were identified as having similar FA compositions, probably due to their relatively close proportions in 16:0, 18:4(n-3) and 16:1(n-7). However, epiphytes had much higher proportions of 20:5(n-3) $(14.6 \%)$ than TPOM $(5.5 \%)$, while TPOM had higher proportions of $18: 1(n-9)$ than epiphytes (23.8 vs. $14.4 \%$ ). SPOM and EOM also had similar FA compositions with close proportions of 16:0 and 18:1(n-9). The trophic markers 20:5(n-3), 14:0, 16:1(n-7) and 18:1(n-7) also had similar proportions in SPOM and EOM. These last 2 food sources were characterized by the highest relative percentages of bacterial FA markers $(7.7$ and $8.6 \%$, respectively) among food sources, while TPOM exhibited only intermediate levels of bacterial FA markers. SPOM had the highest proportion of 22:6(n-3) $(7.2 \%)$ and was followed by TPOM and epiphytes.

\subsection{FA composition of consumers}

Forty-one FAs were identified in consumers, as in the food sources (Table S3 in the Supplement). The percentages of saturated long-chain FAs typical for vascular plants were low in all consumers $(<1 \%)$. Two major groups of consumers could be defined based on the cluster analysis (Fig. 6): a first group including all the filter feeders, 1 omnivore $(H$. araneus) and 1 grazer (Margarites groenlandicus), and a second group including the other grazers and 1 omnivore $(O$. aculeata). Within the first group, an important difference between $M$. groenlandicus and the other consumers was the very low contribution of the flagellate marker 22:6(n-3) in M. groenlandicus. All filter feeders, as well as $H$. araneus, had much higher proportions of 22:6(n-3), ranging from 8.4 to $25.8 \%$, than the other consumers. Filter feeders and $H$. araneus also presented relatively important proportions in other FA trophic markers: 20:5(n-3), 16:1(n-7) and 18:4(n-3). The bivalves Hiatella arctica and Musculus sp., as well as the crustaceans Balanus sp., Caprella septentrionalis and $H$. araneus, were part of the same cluster.

Consumers from the second group, including $T$. rubra, S. droebachiensis and O. aculeata, had relatively high proportions of the diatom FA marker 14:0 (from 7.3 to $8.6 \%$, Fig. 6). Within this group, the 2 grazers (T. rubra and $S$. droebachiensis) had much higher proportions of 20:5(n-3) (6.6 and $12.0 \%$ ) and diatom markers (e.g. 14:0 and 16:1(n-7)) (24.9 and
$12.3 \%$ ) than those of $18: 4(n-3)$ and flagellate markers. It is worth noting that a very similar pattern in FA composition was observed in $M$. groenlandicus, the third grazer analyzed in this study. The omnivore $O$. aculeata had relatively similar proportions of 20:5(n$3)$, diatom and flagellate markers as the grazers but had a much higher contribution of 18:4(n-3) (14.5\%). The highest proportions of the bacteria marker 18:1(n-7) were found in the grazers $M$. groenlandicus $(13.2 \%)$ and T. rubra $(10.0 \%)$. The highest proportion of 20:4(n-6) was measured in the sea urchin $S$. droebachiensis.

\subsection{Two-dimensional analysis on food sources and consumers using $\delta^{13} \mathrm{C}$ values and FA compositions}

The combination of SI and FA data enhanced the differentiation between the potential food sources (Fig. 7). Phaeophyta had $\delta^{13} \mathrm{C}$ values close to many other food sources (i.e. SPOM, EOM, TPOM, epiphytes) but were very well discriminated from them based on FA compositions. The ratios between 20:4(n-6) and 20:5(n-3) in kelp stipes (ranging from 1.6 to 2.8 ) and blades (from 0.5 to 1.0) were indeed much higher than those of SPOM, EOM, TPOM and epiphytes, ranging from 0.1 to 0.2 . Other food sources (i.e. the Rhodophyta P. gunneri and ENRH) were well discriminated based on their much lower $\delta^{13} \mathrm{C}$ values ( -36.7 to $-28.0 \%$ ).

All consumers were relatively enriched in ${ }^{13} \mathrm{C}\left(\delta^{13} \mathrm{C}\right.$ values $>-22.3 \%$ ) and had relatively similar values of the 20:4(n-6)/20:5(n-3) ratios (Fig. 7). These values, ranging from $<0.1$ (H. arctica) to 0.6 (S. droebachiensis), were distinctively lower than most of the values measured in Phaeophyta. The grazers $S$. droebachiensis and T. rubra had the highest 20:4(n-6)/20:5(n-3) ratios, close to those of $A$. esculenta and $S$. dermatodea blades (0.5 and 0.6, respectively). All other consumers had 20:4(n-6)/20:5(n-3) ratio values within the range of epiphytes, EOM, TPOM and SPOM.

\section{DISCUSSION}

\subsection{Discrimination of food sources of macroalgal origin based on their isotope and FA compositions}

Macroalgae, particularly Rhodophyta, had a very wide range of carbon isotope compositions, and $\delta^{13} \mathrm{C}$ values were also very variable within species. These wide ranges of $\delta^{13} \mathrm{C}$ values observed in Kongsfjorden, which are comparable with those measured in 

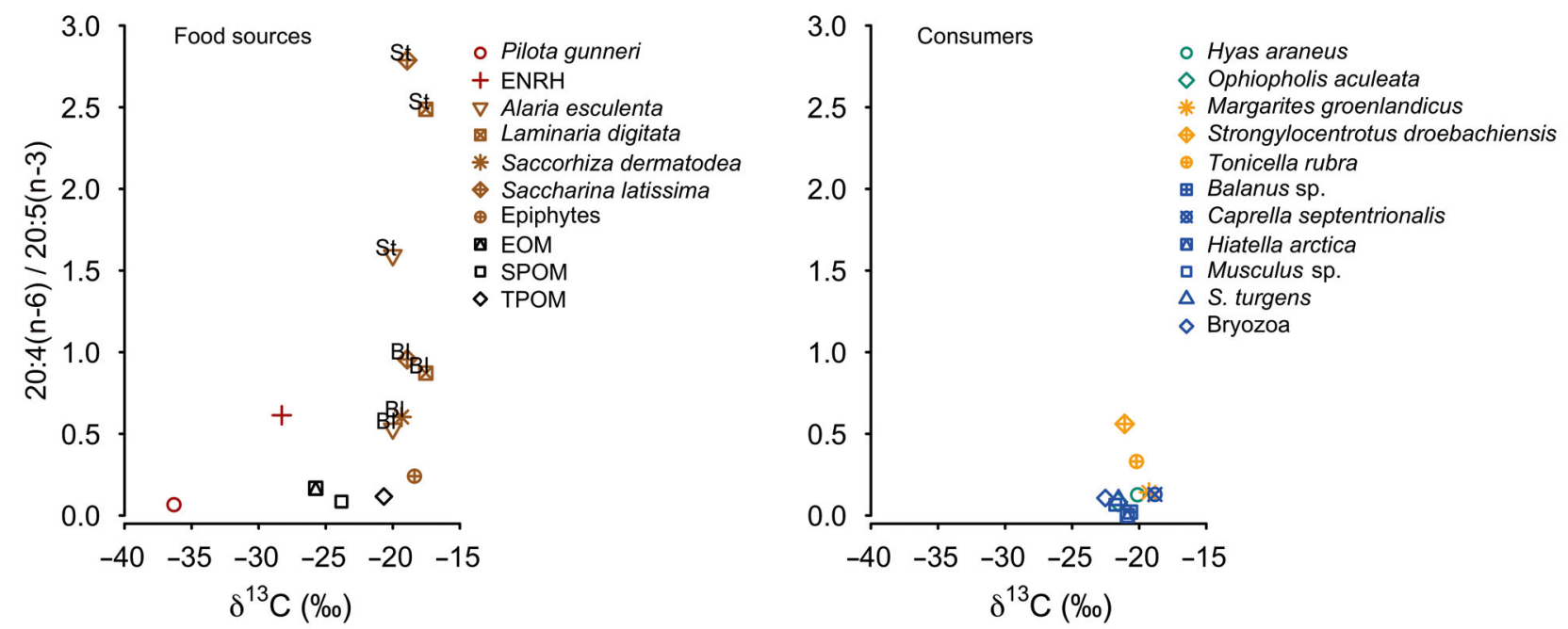

Fig. 7. $\delta^{13} \mathrm{C}$ values (mean) and 20:4(n-6)/20:5(n-3) ratios of potential food sources (left panel) and macrozoobenthos (right panel) collected from June to August 2013 at Hansneset. Omnivore species are displayed in green, grazers in orange, filter feeders in blue. Bl: blades; St: stipes. Other abbreviations as in Fig. 4

other Arctic ecosystems (Sokołowski et al. 2014, Renaud et al. 2015), limit a separation of these primary producers solely based on their $\delta^{13} \mathrm{C}$ values. Differences between Phaeophyta and erect Rhodophyta could nevertheless be observed, with erect Rhodophyta much more ${ }^{13} \mathrm{C}$ depleted $(<-35.8 \%$ ) than Phaeophyta (>-21.0\%), as already observed in Isfjorden (Renaud et al. 2015). $\delta^{13} \mathrm{C}$ values of macroalgae depend on the isotope composition of the available dissolved inorganic carbon and on physiological differences in mechanisms for carbon assimilation (Maberly et al. 1992, Raven et al. 2002). Moreover, carbon isotope composition in primary producers can vary depending on the temperature at low latitudes (Goericke \& Fry 1994), so the variations observed may reflect local effects as well. The differences in $\delta^{13} \mathrm{C}$ values of the detritus pools from 10 and $15 \mathrm{~m}$ depth suggest that they were made of different proportions of macroalgal material (i.e. Phaeophyta, Rhodophyta).

Macroalgal $\delta^{15} \mathrm{~N}$ values were markedly low compared to those measured in northeastern Greenland (Hobson et al. 1995) and the Chukchi Sea (Iken et al. 2010). In shallow areas, light atmospheric nitrogen can play a crucial role during the assimilation of dissolved nitrogen by primary producers under nutrient limitation (Sokołowski et al. 2014). Low concentrations of nutrients can occur during summer months, as demonstrated in Kongsfjorden (van De Poll et al. 2016), and hence might explain the observed relatively low $\delta^{15} \mathrm{~N}$ values of the studied macroalgae.

FAs were more suitable trophic markers to discriminate the different classes of macroalgae, separating well Phaeophyta stipes, Phaeophyta blades and erect Rhodophyta. Rhodophyta and Phaeophyta differed because of the much higher proportions of 20:5(n-3) and 16:0 in Rhodophyta than in Phaeophyta and the higher proportions of 20:4(n-6) and 18:1(n-9) in Phaeophyta than in Rhodophyta (Graeve et al. 2002, Kelly \& Scheibling 2012). It is worth noting that 18:1(n-9) is also abundant in other potential food sources (e.g. TPOM, SPOM, EOM) and should therefore be more considered as a ubiquitous FA in food web studies. Differences in FA composition between algae species growing in the same ecosystem are shaped by class-specific FA synthesis pathways rather than environmental gradients (Graeve et al. 2002). Rhodophyta are phylogenetically among the oldest lineages of macroalgae (van den Hoek et al. 1995), explaining more ancestral FA synthesis pathways, which differ from those of Phaeophyta. Kelp blades and stipes also had very different proportions in characteristic FAs (i.e. 18:3(n-3), 18:4(n-3), 20:4(n-6), 20:5(n-3)), which may be related to the role of these FAs in the cell membrane structure and thylakoid membranes, as well as in the age of the tissue (Schmid \& Stengel, 2015). This highlights that the type of the tissue has to be taken into account as well when considering macroalgae in food web studies.

The combination of bulk SI and FA analyses led to a higher discrimination between food sources of macroalgal origin. Although fresh and detrital matter from erect Rhodophyta were well discriminated from Phaeophyta using SI or FA composition alone, ENRH was only discriminated from Phaeophyta using the combination of SI and FAs (i.e. 20:4(n-6)/20:5(n-3) 
ratio). Isotope compositions of macroalgae can be highly variable, as isotope compositions can change at the individual or species level and can also reflect patterns at larger scales, such as seasons or locations (Dunton \& Schell 1987, Leclerc et al. 2013b). The aging of the material can also affect the isotope composition, leading to its enrichment in ${ }^{13} \mathrm{C}$ (Buchholz \& Wiencke 2016) or ${ }^{15} \mathrm{~N}$ (Leclerc et al. 2013a). As a result, these variations often limit the discrimination of different macroalgae only based on their isotope composition. Moreover, coastal habitats are generally fueled by a large diversity of primary food sources (Lebreton et al. 2011). Isotope compositions of these food sources follow spatio-temporal patterns as well (Goericke \& Fry 1994), leading to the overlapping of the $\delta^{13} \mathrm{C}$ values of primary producers, which limits data interpretation in food web studies (Peterson 1999). The combination of SI and FA trophic markers was already used to overcome some of these shortcomings of SI analysis in systems fueled by macroalgae (Rooker et al. 2006).

\subsection{Composition of epiphytic and epilithic materials}

Epiphytes had SI compositions relatively similar to those of Phaeophyta. At Hansneset, 6 taxa of dominant epiphytic algae were identified on the blades of dominant Laminariales, and all these species were mostly filamentous Phaeophyta: Ectocarpus spp., Laminariocolax aecidioides, Leptonematella fasciculata, Pylaiella varia, P. littoralis, Spacelorbus nanus (Fredriksen et al. 2014). Nevertheless, the FA composition of epiphytes also indicated the presence of diatoms, flagellates and bacteria at the surface of the blades. The development of bacteria is very likely related to the exudates produced by Phaeophyta (Bengtsson et al. 2011), as a large part of their photosynthetic fixed carbon $(\sim 26 \%)$ is released as dissolved organic carbon (Abdullah \& Fredriksen 2004). As a result, epiphytes and macroalgae could be distinguished based on their FA compositions.

EOM had high proportions of diatom FA markers, including 20:5(n-3), highlighting the importance of these microalgae in its composition. An important role of benthic diatoms in the microphytobenthos has already been described in shallow soft-bottom habitats in Kongsfjorden (Woelfel et al. 2009). Diatoms found in the EOM in summer could partly originate from settled phytoplankton, as diatoms dominate during spring bloom events in Kongsfjorden (Søreide et al. 2013) and can reach the bottom as intact cells (Graf 1992). Proportions of bacterial FA markers were also high in EOM, suggesting an additional large contribution of bacteria. EOM had the lowest $\delta^{15} \mathrm{~N}$ values among the potential food sources. Depletion in $\delta^{15} \mathrm{~N}$ values has been observed in diatoms growing under low irradiance conditions (Søreide et al. 2006), as observed under the kelp canopy.

\subsection{Compositions of SPOM and TPOM: trapping of organic matter of pelagic origin under the canopy}

SPOM had a large range of $\delta^{13} \mathrm{C}$ values, comparable to those already reported for Svalbard waters (Søreide et al. 2013, Kuliński et al. 2014) and very likely related to changes in SPOM composition during summer 2013. The much lower $\delta^{13} \mathrm{C}$ values measured during mid-summer $(<-25 \%)$ than at the beginning and end of summer ( $>-25 \%)$ suggest a higher influence of terrestrial organic matter during midsummer. In Kongsfjorden, terrestrial particulate organic matter is more depleted in ${ }^{13} \mathrm{C}$ (i.e. $\delta^{13} \mathrm{C}$ values from -35.2 to $-26.4 \%$ ) than marine organic matter $(-23.9$ to $-15.8 \%$ ) (Kuliński et al. 2014). However, the very low quantities of vascular plant FA markers in SPOM contradict the hypothesis of a potential influence of terrestrial organic matter into SPOM in July.

At the beginning of summer, the very low chl a concentrations and the high proportions of typical flagellate FAs and bacterial FAs, together with low concentrations of diatom FAs, indicate that SPOM was a heterogeneous source dominated by flagellates and other protists as well as detrital material, which is typical of post-bloom situations (Mayzaud et al. 2013). In Kongsfjorden, the phytoplankton spring bloom occurs between April and May and is dominated by diatoms (Renaud et al. 2011, Hodal et al. 2012). Bacteria might have used senescent plankton and fecal pellets as substrates, leading to the high $\delta^{15} \mathrm{~N}$ values of SPOM (Hoch et al. 1996) in June. The higher $\delta^{13} \mathrm{C}$ values and chl a concentration in midAugust 2013 suggested that a second bloom occurred in late summer, as already observed by Renaud et al. (2011).

The SPOM trapped under the kelp canopy (TPOM) $\delta^{13} \mathrm{C}$ values were intermediate between those of SPOM and macroalgae, suggesting a potential influence of macroalgal detritus in its composition. Nevertheless, the very low amount of macroalgal FAs and the very low 20:4(n-6)/20:5(n-3) ratio of TPOM clearly demonstrate that kelp material poorly contributed to TPOM composition. Instead, the relatively high lev- 
els of diatom and flagellate markers highlighted that TPOM was mostly made of microalgae probably from benthic and pelagic origin, as already demonstrated by Sokołowski et al. (2014) in deep soft-bottom habitats in Hornsund (located in the southern part of Spitsbergen). The similar FA profiles of TPOM and SPOM highlight the importance of the flow of organic matter from the water column to the benthic system in this polar fjord. Diatoms found in the TPOM in summer could indeed partly originate from settled phytoplankton, caused by spring bloom events in Kongsfjorden (Søreide et al. 2013). As the kelp canopy lowers hydrodynamics and reduces particle export (Eckman et al. 1989), the flow of organic matter from the water column to the benthic system was probably reinforced because of the dense kelp belt at Hansneset. Kelp species are therefore not only providing diverse habitats for associated fauna but also increasing the magnitude and composition of organic matter channeled through the food web. Temporal variability in organic matter supply might further increase food web complexity, as has been shown for temperate kelp forests (Leclerc et al. 2013).

\subsection{Limited use of macroalgal material by the macrozoobenthos}

Comparisons of isotope compositions of consumers with those of potential food sources-taking into account TFFs - highlight that a broad range of potential food sources could be used by the consumers. These may include Phaeophyta (either fresh or as degraded material), TPOM, SPOM, epiphytes and Chlorophyta but also EOM. Nevertheless, the very ${ }^{13} \mathrm{C}$-depleted composition of erect Rhodophyta (Phycodris rubens and Ptilota gunneri) and ENRH clearly excluded these groups of algae as important food resources in the kelp belt food web.

The relatively low proportions of typical Phaeophyta FA markers in consumers - ranging from $2.0 \%$ (Hiatella arctica) to $9.0 \%$ (Strongylocentrotus droebachiensis) - demonstrated that Phaeophyta have a minor role as a food resource in this food web. As a result, it is likely that the 20:5(n-3) and 18:4(n-3) FA markers measured in consumers mostly originate from diatoms and flagellates, respectively. The FA 20:4(n-6), very abundant in Phaeophyta stipes and blades, was observed in low quantities in tissues of consumers. Accordingly, the ratio 20:4(n-6)/20:5(n-3), which was elevated in Phaeophyta, was considerably low in consumers, confirming the minor role of
Phaeophyta-derived organic matter in the kelp belt food web. Among all consumers, the sea urchin $S$. droebachiensis had the highest relative percentage of 20:4(n-6) and the highest 20:4(n-6)/20:5(n-3) ratio, close to the range of Phaeophyta blades, suggesting that this species was the one relying the most on Phaeophyta in this habitat (Dalsgaard et al. 2003). Kelly et al. (2008) indeed highlighted that kelp material can be highly grazed by $S$. droebachiensis.

High Phaeophyta production (Welch et al. 1992, Abdullah \& Fredriksen 2004) has been assumed to be the main food source in kelp belt food webs. However, fresh Phaeophyta material is seldom grazed directly because of its high C:N ratio and phlorotannin content, and it mostly enters the food chain as detritus (Fredriksen 2003, Miller \& Page 2012), after bacterial degradation (Norderhaug et al. 2003). We demonstrate here that Phaeophyta played a minor role as a food resource in the kelp belt food web, which may be related to the season, as this study was carried out during the Arctic summer. Perennial Phaeophyta have strong seasonal growth cycles sharpened by the strong seasonal light pattern in high latitudes (Wiencke et al. 2009). Expansion of new leaves occurs in winter, fueled by storage metabolites accumulated during the previous summer season, and in summer months, nutrient limitation slows down growth and tissue loss occurs at the blade fronts (Wiencke et al. 2009). Moreover, Phaeophyta species differ clearly in their seasonal cycle regarding onsets of growth and reproduction (Olischläger \&Wiencke 2013). Ongoing Phaeophyta growth might have limited the quantity of kelp detritus in summer; hence, detritus was not available for the belt inhabitant consumers. The low amounts of typical Phaeophyta FA markers in TPOM gave further evidence that the onset of the Phaeophyta deterioration phase did not occur during summer. As a result, it seems that Phaeophyta material, either fresh or detrital, is of minor importance in fueling the Arctic kelp belt food web in summer. However, the role of Phaeophyta material as a food resource might be of more importance during other seasons.

\subsection{Significant role of composite food sources in the kelp belt food web}

The minor role of Phaeophyta as a food source gave strong evidence that the 20:5(n-3), 18:4(n-3) and 18:1(n-7) found in consumers were mostly derived from diatoms, flagellates and bacteria, respectively. As a result, the relatively high proportions of 
diatom markers, including 20:5(n-3), in consumers from all feeding types pointed out their reliance on diatoms as a food source (Graeve et al. 1997, Legeżyńska et al. 2014), with these diatoms possibly originating from both pelagic and benthic compartments. The high proportions of flagellate FA markers in filter feeders underline the importance of senescent phytoplankton as a food resource (Mayzaud et al. 2013). Therefore, composite food sources like SPOM, TPOM and EOM, as well as epiphytes, most likely played a crucial role in the functioning of the studied kelp belt food web.

Filter feeders indeed presented large proportions of diatom FA markers, and studies have already demonstrated that many filter-feeder species assimilate diatoms in other polar ecosystems (Budge et al. 2001, Graeve et al. 2001). Grazers also had high proportions of diatom FA markers. Macrozoobenthic grazers are known to be important consumers of pelagic production in the Arctic, utilizing sedimented phytoplankton and detrital material (Hobson et al. 1995). In the studied kelp belt, diatoms could originate from the phytoplankton as well as from eroded epilithic material (EOM) or epiphytes.

It is likely that these different food resources are trapped within the kelp belt, as large kelp specimens increase particle residence time under their canopy (Eckman et al. 1989), and then significantly contribute to the pool of TPOM available to benthic consumers. Indeed, consumers' intermediate $\delta^{13} \mathrm{C}$ and $\delta^{15} \mathrm{~N}$ values, which were close to TPOM, in combination with information from FA trophic markers suggested that microalgae from benthic and pelagic origin, once sedimented, were utilized by filter feeders and grazers. Consumers from these 2 feeding groups are themselves food sources for omnivores, as highlighted by the higher TLs of these consumers. As a result, kelps not only create a unique ecosystem as they increase habitat complexity but also support a large diversity of macrozoobenthic species (Lippert et al. 2001, Voronkov et al. 2013) that feed on food resources trapped under the kelp canopy.

The low $\delta^{15} \mathrm{~N}$ values of EOM allowed for a good discrimination between EOM and SPOM and epiphytes, these last 2 food sources being more enriched in ${ }^{15} \mathrm{~N}$. The ${ }^{15} \mathrm{~N}$-depleted sea urchin $S$. droebachiensis is likely the species relying the most on EOM, while other consumers with higher $\delta^{15} \mathrm{~N}$ values (such as Margarites groenlandicus and Tonicella rubra) probably rely more on epiphytes and organic matter trapped and settled under the kelp canopy (TPOM). S. droebachiensis predominantly grazes on epibiota of stones and surficial detritus and secondarily in- gests coarse sand to exploit infaunal meiobenthos and organic matter (Gilkinson et al. 1988). The presence of diatom FA markers in the sea urchin gave further evidence that this species relies on microalgae covering the rocky bottom, as already observed by Kelly et al. (2008) in Nova Scotia. The relatively high level of bacterial FA markers in the gastropod M. groenlandicus and the chiton T. rubra indicated that these species used bacteria as a food source.

Filter feeders were separated from grazers based on their high amounts of flagellate FA markers, including 18:4(n-3), highlighting a strong reliance of these consumers on phytoplankton. Like diatoms, flagellates could originate from pelagic phytoplankton, particularly in early summer, as the post-bloom state is dominated by ciliates and flagellates (Mayzaud et al. 2013). A possible role of eroded epiphytes should also be considered, as epiphytes also contained relatively high proportions of flagellate markers. The variations in flagellate FA marker contributions observed among filter feeders may be related to selection and assimilation processes. Bryozoans, being the most dependent on flagellates, might preferentially select flagellates, based on their smaller size (Søreide et al. 2008), and assimilate them better because of their high content in essential FAs. In Antarctica, bryozoans were observed to efficiently use microplankton (Barnes \& Clarke 1994).

The 2 omnivore species analyzed for FA composition in this study also had relatively high proportions of flagellate FA markers, probably for different reasons. The brittle star O. aculeata is a deposit-feeder species which grazes on epiphytes and deposited detrital material but is also known to act episodically as a filter feeder (Graeve et al. 1997). The similarity in FA compositions between Hyas araneus and filter feeders indicates that they can be an important food resource for $H$. araneus, probably through predation and scavenging, which represents an indirect connection between the pelagic and the benthic systems. But this connection may also be direct, as Legeżyńska et al. (2014) indicated that $H$. araneus may rely on relatively large macrozooplankton as well. The highest $\delta^{15} \mathrm{~N}$ values of $H$. araneus among the macrofaunal community gave further evidence that this species is the one relying the most on animals as food resources, as already described in Svalbard (Berge et al. 2009), and in temperate waters, where it is known to be able to handle and consume bivalves (Nadeau \& Cliché 1998).

The role of each of these different composite food sources (i.e. SPOM, TPOM, EOM, epiphytes) could 
be better defined with a greater comprehension of the TFF between food sources and consumers as well as an improvement of the knowledge about turnover rate of tissues. In a literature review, Caut et al. (2009) showed that the variability of TFF for carbon and nitrogen mainly depends on the taxonomic group (e.g. invertebrate, fish, mammal), tissue and isotope composition of the primary producers. The processes of assimilation-leading to similar isotope and FA compositions between primary sources and consumers - in macrozoobenthic consumers are mainly driven by ontogenetic status, growth rates, species-specific physiological differences and abiotic parameters (Caut et al. 2009, Kelly \& Scheibling 2012). The information used in this study were nevertheless sufficient to highlight the minor role of kelp material and the important role of composite food sources in this food web, at this season, based on the large differences in SI compositions between erect Rhodophyta and kelp and the low proportions of kelp FA trophic markers in consumers. Moreover, in Kongsfjorden, controlled feeding experiments (Wessels et al. 2012) and field observation (McMahon et al. 2006) demonstrated the assimilation of dietary SI and FA compositions by Arctic benthic invertebrates within 1 mo. Benthic systems are well suited for trophic marker studies because of the relatively long life spans of consumers and their sessile lifestyles, leading to the integration of the signatures of their food sources over months to decades (Renaud et al. 2011).

\subsection{Role of kelp belts in the functioning of the Kongsfjorden ecosystem during summer}

Macroalgal belts, mostly consisting of kelp (Hop et al. 2012), cover $44 \%$ of the subtidal area comprised from 0 to $10 \mathrm{~m}$ in Kongsfjorden (Kruss et al. 2008, Woelfel et al. 2010). Kelp annual primary production ranges from 400 to $1900 \mathrm{~g} \mathrm{C} \mathrm{m}^{-2} \mathrm{yr}^{-1}$ (Welch et al. 1992, Abdullah \& Fredriksen 2004), which considerably exceeds the pelagic primary production in Kongsfjorden (ranging from 27 to $35 \mathrm{~g} \mathrm{C} \mathrm{m}^{-2} \mathrm{yr}^{-1}$, Hodal et al. 2012). In addition to effects at the habitat scale, the presence of kelp belts and the development of their biomass in relation to biotic and abiotic parameters (Bartsch et al. 2016) have several major implications at the scale of the entire fjord. Detached macroalgae and their detritus can contribute significantly to both the shallow and deep benthic food webs, as demonstrated in the Isfjorden (Renaud et al. 2015). The accumulation of macro- algal detrital material in soft-bottom systems very likely creates a strong flow of matter and energy between rocky shores and sedimentary coastal habitats. In addition to flows related to hydrodynamics, exports of organic matter by biotic vectors should also be taken into consideration. Several fish species colonize kelp belts for the purpose of foraging (Norderhaug et al. 2005, Brand \& Fischer 2016) and then move between several habitats or even migrate (Cote et al. 2004). The magnitude of these flows will need to be assessed and quantified in future studies.

On a temporal basis, kelp belt food web dynamics in summer may be very different compared to other seasons. As previously stated, the functioning of the kelp belt food web is driven by a seasonal cycle, with strong pulsed primary production occurring in spring and summer (Hanelt et al. 2001, Hodal et al. 2012) and decaying of organic matter occurring in fall and winter (Wiencke et al. 2009, Olischläger \& Wiencke 2013). The strong seasonal variations occurring in these ecosystems probably lead to large changes in the biomass and quality of food resources, with cascading effects in the dynamics of the kelp belt food web and likely for adjacent habitats. Thus, a need for a better understanding of the functioning of kelp belt food webs on a seasonal basis in polar areas exists. The obtained knowledge will give further insights into the effects of climate change on polar coastal ecosystems.

\section{CONCLUSIONS}

The remarkable low use of macroalgae-derived material by the kelp belt inhabitant fauna contrasts with the large kelp biomass and production in the shallow rocky shores of Kongsfjorden. During summer, benthic consumers can rely on a great variety of food resources of benthic and pelagic origin. Microalgae (i.e. diatoms and flagellates) can originate from the senescent phytoplankton bloom, suspended epilithic material or eroded epiphytes and are likely trapped under the kelp belt canopy. This flow of organic matter from the water column to the benthos supports a diverse macrozoobenthic community and consequently increases the complexity of the food web. As several food resources are entering the kelp belt food web, their redundancy might compensate for the short and pulsed production occurring in Arctic coastal waters. Future studies will have to take into account the effect of pronounced seasonal variations, which occur in polar ecosystems, as they may lead to considerable variation in how organic matter is channeled through the kelp belt food web. 
Acknowledgements. This work is part of the long-term project KOL 06 'The biology of Arctic benthic algae' and was conducted at the International Arctic Environmental Research and Monitoring Facility at Ny-Ålesund, Spitsbergen, Norway. We thank the members of the diving team under the supervision of M. Schwanitz, the AWIPEV Arctic Research Base and Kings Bay for their great support. We acknowledge Gaël Guillou for analyzing the SI samples presented in this study. The authors acknowledge the 3 anonymous reviewers for their useful comments.

\section{LITERATURE CITED}

Abdullah MI, Fredriksen S (2004) Production, respiration and exudation of dissolved organic matter by the kelp Laminaria hyperborea along the west coast of Norway. J Mar Biol Assoc UK 84:887-894

Aitchison J, Barceló-Vidal C, Martín-Fernández JA, Pawlowsky-Glahn V (2000) Logratio analysis and compositional distance. Math Geol 32:271-275

* Bannon CD, Craske JD, Hilliker AE (1986) Analysis of fatty acid methyl esters with high accuracy and reliability. Validation of theoretical relative response factors of unsaturated esters in the flame ionization detector. J Am Oil Chem Soc 63:105-110

* Barnes DKA, Clarke A (1994) Seasonal variation in the feeding activity of four species of Antarctic bryozoan in relation to environmental factors. J Exp Mar Biol Ecol 181: 117-133

Bartsch I, Paar M, Fredriksen S, Schwanitz M, Daniel C, Hop $\mathrm{H}$, Wiencke C (2016) Changes in kelp forest biomass and depth distribution in Kongsfjorden, Svalbard, between 1996-1998 and 2012-2014 reflect Arctic warming. Polar Biol 39:2021-2036

Bengtsson MM, Sjøtun K, Storesund JE, Øvreås L (2011) Utilization of kelp-derived carbon sources by kelp surfaceassociated bacteria. Aquat Microb Ecol 62:191-199

*Beninger PG, Le Pennec M, Donval A (1991) Mode of particle ingestion in five species of suspension-feeding bivalve molluscs. Mar Biol 108:255-261

* Berge J, Renaud PE, Eiane K, Gulliksen B, Cottier FR, Varpe $\varnothing$, Brattegard T (2009) Changes in the decapod fauna of an Arctic fjord during the last 100 years (1908-2007). Polar Biol 32:953-961

* Brand M, Fischer P (2016) Species composition and abundance of the shallow water fish community of Kongsfjorden, Svalbard. Polar Biol 39:2155-2167

Brown TA, Belt ST, Piepenburg D (2012) Evidence for a panArctic sea-ice diatom diet in Strongylocentrotus spp. Polar Biol 35:1281-12879

* Buchholz CM, Wiencke C (2016) Working on a baseline for Kongsfjorden food web: production and properties of macroalgal particulate organic matter (POM). Polar Biol 39:2053-2064

Budge SM, Parrish CC, McKenzie CH (2001) Fatty acid composition of phytoplankton, settling particulate matter and sediments at a sheltered bivalve aquaculture site. Mar Chem 76:285-303

* Caut S, Angulo E, Courchamp F (2009) Variation in discrimination factors $\left(\Delta^{15} \mathrm{~N}\right.$ and $\left.\Delta^{13} \mathrm{C}\right)$ : the effect of diet isotopic values and applications for diet reconstruction. J Appl Ecol 46:443-453

Cebrian J (1999) Patterns in the fate of production in plant communities. Am Nat 154:449-468
Christie WW (1984) Extraction and hydrolysis of lipids and some reactions of their fatty acid components. In: Zweig G, Sherma J (eds) Handbook of chromatography, lipids, Vol 1. CRC Press, Boca Raton, FL, p 33-46

Christie WW (1988) Equivalent chain-lengths of methyl ester derivatives of fatty acids on gas chromatographya reappraisal. J Chromatogr A 447:305-314

* Connelly TL, Deibel D, Parrish CC (2014) Trophic interactions in the benthic boundary layer of the Beaufort Sea shelf, Arctic Ocean: combining bulk stable isotope and fatty acid signatures. Prog Oceanogr 120:79-92

* Cote D, Moulton S, Frampton PCB, Scruton DA, McKinley RS (2004) Habitat use and early winter movements by juvenile Atlantic cod in a coastal area of Newfoundland. J Fish Biol 64:665-679

Cottier F, Tverberg V, Inall M, Svendsen H, Nilsen F, Griffiths C (2005) Water mass modification in an Arctic fjord through cross-shelf exchange: the seasonal hydrography of Kongsfjorden, Svalbard. J Geophys Res 110:C12005

* Cottier FR, Nilsen F, Inall ME, Gerland S, Tverberg V, Svendsen H (2007) Wintertime warming of an Arctic shelf in response to large-scale atmospheric circulation. Geophys Res Lett 34:L10607

*Dalsgaard J, St. John M, Kattner G, Müller-Navarra D, Hagen W (2003) Fatty acid trophic markers in the pelagic marine environment. Adv Mar Biol 46:225-340

* Dunton KH, Schell DM (1987) Dependence of consumers on macroalgal (Laminaria solidungula) carbon in an arctic kelp community: $\delta^{13} \mathrm{C}$ evidence. Mar Biol 93:615-625

* Eckman JE, Duggins DO (1989) Ecology of understory kelp environments. I. Effects of kelps on flow and particle transport. J Exp Mar Biol Ecol 129:173-187

Eckman JE, Duggins DO, Sewell AT (1993) Effects of flow speed on growth of benthic suspension feeders. Biol Bull 185:28-41

Folch J, Lees M, Sloane Stanley GH (1957) A simple method for the isolation and purification of total lipides from animal tissues. J Biol Chem 226:497-509

Fredriksen S (2003) Food web studies in a Norwegian kelp forest based on stable isotope $\left(\delta^{13} \mathrm{C}\right.$ and $\left.\delta^{15} \mathrm{~N}\right)$ analysis. Mar Ecol Prog Ser 260:71-81

Fredriksen S, Bartsch I, Wiencke C (2014) New additions to the benthic marine flora of Kongsfjorden, western Svalbard, and comparison between 1996/1998 and 2012/ 2013. Bot Mar 57:203-216

Gilkinson KD, Gagnon JM, Schneider DC (1988) The sea urchin Strongylocentrotus pallidus (G.O. Sars) on the Grand Bank of Newfoundland. In: Burke RD, Mladenov PV, Lampert P (eds) Echinoderm biology. Balkema, Rotterdam, p 467-473

Giraudoux P (2015) pgirmess: data analysis in ecology. $\mathrm{R}$ package version 1.6.3. http://CRAN.R-project.org/ package=pgirmess (accessed 15 May 2017)

Goericke R, Fry B (1994) Variation of marine plankton $\delta^{13} \mathrm{C}$ with latitude, temperature, and dissolved $\mathrm{CO}_{2}$ in the world ocean. Global Biogeochem Cycles 8:85-90

Graeve M, Kattner G, Piepenburg D (1997) Lipids in Arctic benthos: Does the fatty acid and alcohol composition reflect feeding and trophic interactions? Polar Biol 18: 53-61

Graeve M, Dauby P, Scailteur Y (2001) Combined lipid, fatty acid and digestive tract content analyses: a penetrating approach to estimate feeding modes of Antarctic amphipods. Polar Biol 24:853-862

* Graeve M, Kattner G, Wiencke C, Karsten U (2002) Fatty 
acid composition of Arctic and Antarctic macroalgae: indicator of phylogenetic and trophic relationships. Mar Ecol Prog Ser 231:67-74

Graf G (1992) Benthic-pelagic coupling: a benthic view. Oceanogr Mar Biol Annu Rev 30:149-190

Greenacre M (2011a) Measuring subcompositional incoherence. Math Geosci 43:681-693

Greenacre M (2011b) A simple permutation test for clusteredness. Department of Economics and Business Working Paper 1271, Universitat Pompeu Fabra, Barcelona

Greenacre M (2016) Data reporting and visualization in ecology. Polar Biol 39:2189-2205

* Guerra-García JM, Tierno de Figueroa JM (2009) What do caprellids (Crustacea: Amphipoda) feed on? Mar Biol 156:1881-1890

Hanelt D, Tüg H, Bischof K, Groß C, Lippert H, Sawall T, Wiencke C (2001) Light regime in an Arctic fiord: a study related to stratospheric ozone depletion as a basis for determination of UV effects on algal growth. Mar Biol 138:649-658

Himmelman JH, Hamel JR (1993) Diet, behaviour and reproduction of the whelk Buccinum undatum in the northern Gulf of St. Lawrence, eastern Canada. Mar Biol 116:423-430

Hobson KA, Ambrose WG Jr, Renaud PE (1995) Sources of primary production, benthic-pelagic coupling, and trophic relationships within the Northeast Water Polynya: insights from $\delta^{13} \mathrm{C}$ and $\delta^{15} \mathrm{~N}$ analysis. Mar Ecol Prog Ser 128:1-10

Hoch MP, Synder RA, Cifuentes LA, Coffin RB (1996) Stable isotope dynamics of nitrogen recycled during interactions among marine bacteria and protists. Mar Ecol Prog Ser 132:229-239

Hodal H, Falk-Petersen S, Hop H, Kristiansen S, Reigstad M (2012) Spring bloom dynamics in Kongsfjorden, Svalbard: nutrients, phytoplankton, protozoans and primary production. Polar Biol 35:191-203

*Hop H, Wiencke C, Vögele B, Kovaltchouk NA (2012) Species composition, zonation, and biomass of marine benthic macroalgae in Kongsfjorden, Svalbard. Bot Mar 55

Iken K, Bluhm B, Dunton K (2010) Benthic food-web structure under differing water mass properties in the southern Chukchi Sea. Deep Sea Res II 57:71-85

Jacob U, Mintenbeck K, Brey T, Knust R, Beyer K (2005) Stable isotope food web studies: a case for standardized sample treatment. Mar Ecol Prog Ser 287:251-253

光ędra M, Kuliński K, Walkusz W, Legeżyńska J (2012) The shallow benthic food web structure in the high Arctic does not follow seasonal changes in the surrounding environment. Estuar Coast Shelf Sci 114:183-191

Kelly JR, Scheibling RE (2012) Fatty acids as dietary tracers in benthic food webs. Mar Ecol Prog Ser 446:1-22

Kelly JR, Scheibling RE, Iverson SJ, Gagnon P (2008) Fatty acid profiles in the gonads of the sea urchin Strongylocentrotus droebachiensis on natural algal diets. Mar Ecol Prog Ser 373:1-9

Kraft A, Graeve M, Janssen D, Greenacre M, Falk-Petersen S (2015) Arctic pelagic amphipods: lipid dynamics and life strategy. J Plankton Res 37:790-807

Kruss A, Blondel P, Tegowski J, Wiktor J, Tatarek A (2008) Estimation of macrophytes using single-beam and multibeam echosounding for environmental monitoring of arctic fjords (Kongsfjord, West Svalbard Island). J Acoust Soc Am 123:3213
Kuliński K, Kędra M, Legeżyńska J, Gluchowska M, Zaborska A (2014) Particulate organic matter sinks and sources in high Arctic fjord. J Mar Syst 139:27-37

* Latyshev NA, Khardin AS, Kasyano SP, Ivanova MB (2004) A study on the feeding ecology of chitons using analysis of gut contents and fatty acid analysis. J Molluscan Stud 70:225-230

* Lebreton B, Richard P, Galois R, Radenac G and others (2011) Trophic importance of diatoms in an intertidal Zostera noltii seagrass bed: evidence from stable isotope and fatty acid analyses. Estuar Coast Shelf Sci 92: 140-153

KLeclerc JC, Riera P, Leroux C, Lévêque L, Davoult D (2013a) Temporal variation in organic matter supply in kelp forests: linking structure to trophic functioning. Mar Ecol Prog Ser 494:87-105

* Leclerc JC, Riera P, Leroux C, Lévêque L, Laurans M, Schaal G, Davoult D (2013b) Trophic significance of kelps in kelp communities in Brittany (France) inferred from isotopic comparisons. Mar Biol 160:3249-3258

*Legeżyńska J, Kędra M, Walkusz W (2014) Identifying trophic relationships within the high Arctic benthic community: How much can fatty acids tell? Mar Biol 161: 821-836

Kippert H, Iken K, Rachor E, Wiencke C (2001) Macrofauna associated with macroalgae in the Kongsfjord (Spitsbergen). Polar Biol 24:512-522

* Maberly SC, Raven JA, Johnston AM (1992) Discrimination between ${ }^{12} \mathrm{C}$ and ${ }^{13} \mathrm{C}$ marine plants. Oecologia 91:481-492

* McMahon KW, Ambrose WG Jr, Johnson BJ, Sun MY, Lopez GR, Clough LM, Carroll ML (2006) Benthic community response to ice algae and phytoplankton in Ny Ålesund, Svalbard. Mar Ecol Prog Ser 310:1-14

Mann KH (2000) Ecology of coastal waters, with implications for management, Vol 2. Blackwell Science, Oxford

*Mayzaud P, Boutoute M, Noyon M, Narcy F, Gasparini S (2013) Lipid and fatty acids in naturally occurring particulate matter during spring and summer in a high arctic fjord (Kongsfjorden, Svalbard). Mar Biol 160:383-398

* Miller RJ, Page HM (2012) Kelp as a trophic resource for marine suspension feeders: a review of isotope-based evidence. Mar Biol 159:1391-1402

Murdoch D, Chow ED (2018). Ellipse: functions for drawing ellipses and ellipse-like confidence regions. R package version 0.4.1. https://CRAN.R-project.org/package=ellipse (accessed 15 May 2018)

Murtagh F (2005) Correspondence analysis and data coding with R and Java. Chapman \& Hall / CRC, Boca Raton, FL. www.multiresolutions.com/mda-sw/correspondances/ hcluswtd.r (accessed 16 March 2018)

Nadeau M, Cliché G (1998) Predation of juvenile sea scallops (Placopecten magellanicus) by crabs (Cancer irroratus and Hyas sp.) and starfish (Asterias vulgaris, Leptasterias polaris, and Crossaster papposus). J Shellfish Res 17:905-910

* Nielsen AM, Eriksen NT, Iversen JJL, Riisgård HU (1995) Feeding, growth and respiration in the polychaetes Nereis diversicolor (facultative filter-feeder) and N. virens (omnivorous) - a comparative study. Mar Ecol Prog Ser 125:149-158

Norderhaug KM, Fredriksen S, Nygaard K (2003) Trophic importance of Laminaria hyperborea to kelp forest consumers and the importance of bacterial degradation to food quality. Mar Ecol Prog Ser 255:135-144

*Norderhaug KM, Christie H, Fosså JH, Fredriksen S (2005) 
Fish-macrofauna interactions in a kelp (Laminaria hyperborea) forest. J Mar Biol Assoc UK 85:1279-1286

K Olischläger M, Wiencke C (2013) Seasonal fertility and combined effects of temperature and UV-radiation on Alaria esculenta and Laminaria digitata (Phaeophyceae) from Spitsbergen. Polar Biol 36:1019-1029

Paar M, Voronkov A, Hop H, Brey T and others (2016) Temporal shift in biomass and production of macrozoobenthos in the macroalgal belt at Hansneset, Kongsfjorden, after 15 years. Polar Biol 39:2065-2076

Petersen JK (2007) Ascidian suspension feeding. J Exp Mar Biol Ecol 342:127-137

Petersen JK, Sejr MK, Larsen JEN (2003) Clearance rates in the Arctic bivalves Hiatella arctica and Mya sp. Polar Biol 26:334-341

Peterson BJ (1999) Stable isotopes as tracers of organic matter input and transfer in benthic food webs: a review. Acta Oecol 20:479-487

Post DM (2002) Using stable isotopes to estimate trophic position: models, methods, and assumptions. Ecology 83: 703-718

* Promi ska A, Cisek M, Walczowski W (2017) Kongsfjorden and Hornsund hydrography-comparative study based on a multiyear survey in fjords of west Spitsbergen. Oceanologia 59:397-412

R Core Team (2018) R: a language and environment for statistical computing. R Foundation for Statistical Computing, Vienna

Rajendran N, Suwa Y, Urushigawa Y (1993) Distribution of phospholipid ester-linked fatty acid biomarkers for bacteria in the sediment of Ise Bay, Japan. Mar Chem 42: 39-56

Raven JA, Johnston AM, Kübler JE, Korb R and others (2002) Mechanistic interpretation of carbon isotope discrimination by marine macroalgae and seagrasses. Funct Plant Biol 29:355-378

* Renaud PE, Tessmann M, Evenset A, Christensen GN (2011) Benthic food-web structure of an Arctic fjord (Kongsfjorden, Svalbard). Mar Biol Res 7:13-26

* Renaud PE, Løkken TS, Jørgensen LL, Berge J, Johnson BJ (2015) Macroalgal detritus and food-web subsidies along an Arctic fjord depth-gradient. Front Mar Sci 2:31

Rooker JR, Turner JP, Holt SA (2006) Trophic ecology of Sargassum-associated fishes in the Gulf of Mexico determined from stable isotopes and fatty acids. Mar Ecol Prog Ser 313:249-259

Schlitzer R (2018) Ocean Data View. www.//odv.awi.de (accessed 3 November 2018)

Schmid M, Stengel DB (2015) Intra-thallus differentiation of fatty acid and pigment profiles in some temperate Fucales and Laminariales. J Phycol 51:25-36

Sokołowski A, Szczepałska A, Richard P, Kędra M, Wołowicz M, Węsławski JM (2014) Trophic structure of the macrobenthic community of Hornsund, Spitsbergen, based on the determination of stable carbon and nitrogen isotopic signatures. Polar Biol 37:1247-1260

Søreide JE, Hop H, Carroll ML, Falk-Petersen S, Hegseth EN (2006) Seasonal food web structures and sympagicpelagic coupling in the European Arctic revealed by stable isotopes and a two-source food web model. Prog Oceanogr 71:59-87

Søreide JE, Falk-Petersen S, Hegseth EN, Hop H, Carroll ML, Hobson KA, Blachowiak-Samolyk K (2008) Seasonal feeding strategies of Calanus in the high-Arctic Svalbard region. Deep Sea Res II 55:2225-2244

* Søreide JE, Carroll ML, Hop H, Ambrose WG Jr, Hegseth EN, Falk-Petersen S (2013) Sympagic-pelagic-benthic coupling in Arctic and Atlantic waters around Svalbard revealed by stable isotopic and fatty acid tracers. Mar Biol Res 9:831-850

Svendson H, Beszczynska-Møller A, Hagen JO, Lefauconnier B and others (2002) The physical environment of Kongsfjorden-Krossfjorden, an Arctic fjord system in Svalbard. Polar Res 21:133-166

* van de Poll WH, Maat DS, Fischer P, Rozema PD and others (2016) Atlantic advection driven changes in glacial meltwater: effects on phytoplankton chlorophyll-a and taxonomic composition in Kongsfjorden, Spitsbergen. Front Mar Sci 3:200

van den Hoek C, Mann DG, Jahns HM (1995) Algae: an introduction to phycology. Cambridge University Press, Cambridge

* Viso AC, Pesando D, Bernard P, Marty JC (1993) Lipid components of the Mediterranean seagrass Posidonia oceanica. Phytochemistry 34:381-387

Volkman JK, Jeffrey SW, Nichols PD, Rogers GI, Garland CD (1989) Fatty acid and lipid composition of 10 species of microalgae used in mariculture. J Exp Mar Biol Ecol 128:219-240

*Voronkov A, Hop H, Gulliksen B (2013) Diversity of hardbottom fauna relative to environmental gradients in Kongsfjorden, Svalbard. Polar Res 32:11208

* Wangensteen B, Eiken T, Ødegård RS, Sollid JL (2007) Measuring coastal cliff retreat in Kongsfjorden area, Svalbard, using terrestrial photogrammetry. Polar Res 26:14-21

* Welch HE, Bergmann MA, Siferd TD, Martin KA and others (1992) Energy flow through the marine ecosystem of the Lancaster Sound region, Arctic Canada. Arctic 45: 343-357

WWessels H, Karsten U, Wiencke C, Hagen W (2012) On the potential of fatty acids as trophic markers in Arctic grazers: feeding experiments with sea urchins and amphipods fed nine diets of macroalgae. Polar Biol 35:555-565

Wiencke C, Vögele B, Kovaltchouk NA, Hop H (2004) Species composition and zonation of marine benthic macroalgae at Hansneset in Kongsfjorden, Svalbard. Ber Polarforsch 492:55-62

*Wiencke C, Gómez I, Dunton K (2009) Phenology and seasonal physiological performance of polar seaweeds. Bot Mar 52:585-592

*Włodarska-Kowalczuk M, Kukliński P, Ronowicz M, Legeżyńska J, Gromisz S (2009) Assessing species richness of macrofauna associated with macroalgae in Arctic kelp forests (Hornsund, Svalbard). Polar Biol 32:897-905

Woelfel J, Schumann R, Peine F, Flohr A and others (2010) Microphytobenthos of Arctic Kongsfjorden (Svalbard, Norway): biomass and potential primary production along the shore line. Polar Biol 33:1239-1253

Wold A, Jæger I, Hop H, Gabrielsen GW, Falk-Petersen S (2011) Arctic seabird food chains explored by fatty acid composition and stable isotopes in Kongsfjorden, Svalbard. Polar Biol 34:1147-1155

Zajączkowski M (2008) Sediment supply and fluxes in glacial and outwash fjords, Kongsfjorden and Adventfjorden, Svalbard. Pol Polar Res 29:59-72

Submitted: June 20, 2018; Accepted: March 6, 2019

Proofs received from author(s): April 15, 2019 